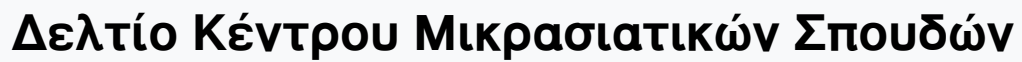

Tóp. 5 (1984)

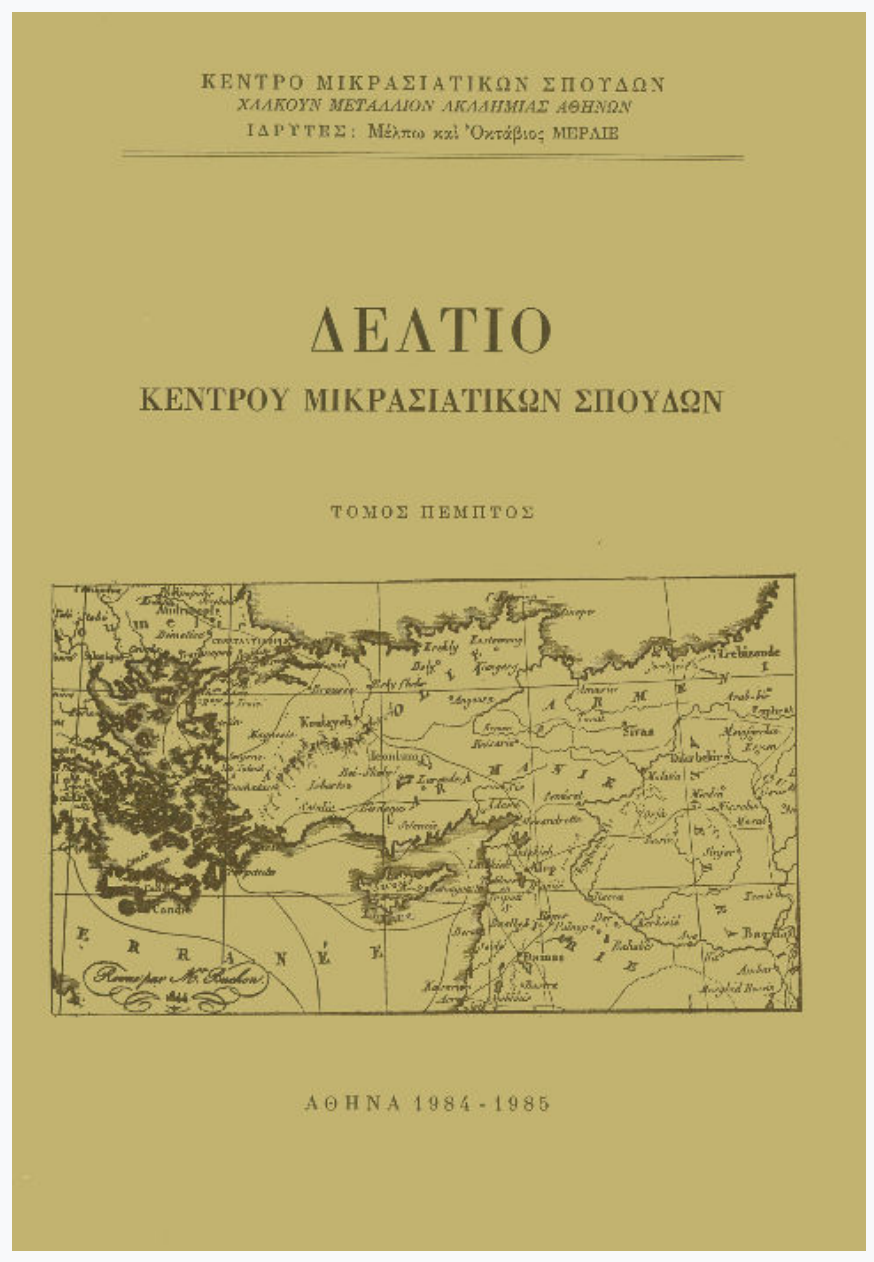

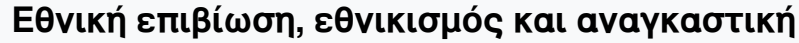

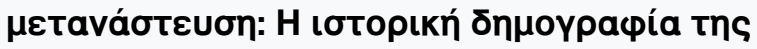

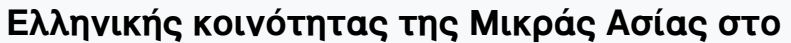

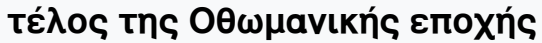

Paschalis M. Kitromilides, Alexis Alexandris

doi: $\underline{10.12681 / \text { deltiokms.205 }}$

Copyright $\odot 2015$, Paschalis M. Kitromilides, Alexis Alexandris

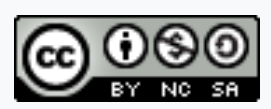

Ađฮsı Xpńбnৎ Creative Commons Attribution-NonCommercial-ShareAlike 4.0.

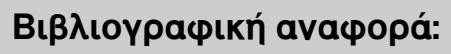

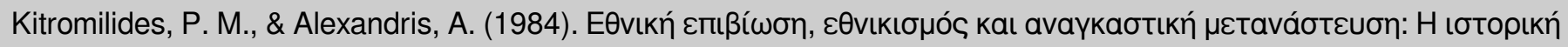

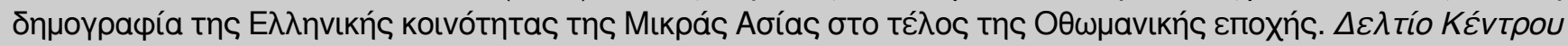

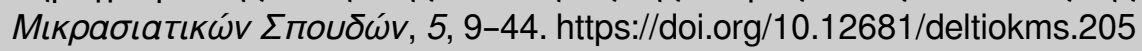




\section{ETHNIC SURVIVAL, NATIONALISM AND FORCED MIGRATION The historical demography of the Greek community of Asia Minor at the close of the Ottoman era}

\section{Introductory}

An important new trend in Ottoman studies focuses on the historical demography of the Ottoman Empire. A number of scholars have attempted in recent years to reconstruct the evolution of the population in various parts and provinces of the Empire. The great interest of these studies consists in the new documentation they bring to light from the non-generally accessible Ottoman archives ${ }^{1}$. The historical demography of more recent times, especially of the nineteenth century, can be documented on the basis of official censuses and other population registers $^{2}$. Both the interests of the researchers and the character of the

We wish to acknowledge our gratitude to Professor Speros Vryonis, Jr., of the University of California, Los Angeles, for his encouragement and his valuable comments on an earlier draft of this paper. Professor Justin McCarthy, who originally suggested the idea of this article, also made useful comments on earlier drafts.

1. Ömer Bärkan, «Essai sur les données statistiques des registres de recensement dans l'empire ottoman aux $\mathrm{XV}^{\mathrm{e}}$ et $\mathrm{XVI}^{\mathrm{e}}$ siècles», Journal of the Economic and Social History of the Orient, vol. I, no 1 (1957), pp. 9-36, on the Ottoman censuses of 1520-1535 and 1570-1580. See also M. A. Cook, Population pressure in rural Anatolia, 1450 - 1600, London 1972 and Ronald C. Jennings, "Urban Population in Anatolia in the Sixteenth Century: A Study of Kayseri, Karaman, Amasya, Trabzon and Erzurum», International Journal of Middle East Studies, vol. 7, no 1 (January 1976), pp. 21-57. On the official legal regulation of the censuses cf. Irene Beldiceanu-Steinherr - N. Beldiceanu, «Règlement ottoman concernant le recensement (première moitié du XVI $\mathrm{XI}^{\mathrm{e}}$ siècle)"), Südost forschungen, vol. 37 (1978), pp. 1-40.

2. Kemal H. Karpat, «Ottoman Population Records and the Census of 1881/1882-1893», International Journal of Middle East Studies, vol. 9 (1978), pp. 
sources used in these studies, however, tend, almost inescapably, to skew the overall demographic perspective represented in these studies. As a consequence we have a general trend to overestimate the Turkish at the expense of other ethnic elements in the population of the Ottoman Empire. This tends to be even more so the case in demographic studies of more recent and therefore politically more sensitive times, especially the period of the dissolution of the Ottoman Empire, extending roughly from 1878 to 1920 . To balance this partiality and reach a more precise picture of both the quantitative magnitudes and the ethnic composition of Ottoman population, the evidence of other censuses, archival and documentary sources should be consulted. The pluralism of source material might provide the needed corrective to the often imperceptible and unconscious biases in-built in historical research. In this spirit the present article attempts to adduce its contribution to the scholarly debate on Ottoman historical demography by bringing to light a body of hitherto unknown data.

The phenomenon of legally recognized ethnic communities coexisting in Asia Minor and the Balkans had been a distinct feature of Ottoman politics. In this context, the Greek communities of Asia Minor were able to survive in their ancestral hearths from Byzantine times into the twentieth century, despite the dislocations caused by the centuries-long confrontation of Christianity and Islam in their homeland. Their eventual survival in Asia Minor, however, was precluded by the emergence of the disruptive force of nationalism, whose impact they felt in the late nineteenth and early twentieth century.

The establishment of national states in Southeastern Europe and the diffusion of ethnic nationalism among the racial and religious groups in Asia Minor, particularly during the Balkan Wars of 1912-1913, resulted in

237-274 and idem, Ottoman Population 1830-1914, London 1985. See also Stanford J. Shaw, «The Ottoman Census System and Population, 1831-1914», International Journal of Middle East Studies, vol. 9, no. 3 (August 1978), pp. 325-338 and Justin McCarthy, «Age, Family and Migration in Nineteenth Century Black Sea Provinces of the Ottoman Empire», International Journal of Middle East Studies, vol. 10, no 3 (August 1979), pp. 309-323. Finally see the useful collection of statistical data by Justin McCarthy, The Arab World, Turkey, and the Balkans (1978-1914): A Handbook of Historical Statistics, Boston, Mass. 1982, esp. pp. 53-106. 
serious intercommunal rivalries. Nationalism undermined, and ultimately obliterated, the delicate balance of the existing multiethnic structure which had ensured the symbiosis of the autochthonous inhabitants of Asia Minor. The final outcome of the new ethnic antagonism, which at the same time became entangled in international conflicts during the First World War, was the violent expulsion of the geographically dispersed and vulnerable Anatolian Greeks from their homelands. This formed an integral part of the large-scale forceful movement of people who paid the human cost of the emergence of nation states in the Middle East.

The first part of this article examines the pattern of Greek settlement in Asia Minor as well as the Greek migratory movements before 1922-1923. The second section deals with the quantitative aspect of the problem. It considers the issue of Greek and Ottoman population statistics and evaluates their accuracy. The study concludes with a survey of the forms taken by the exodus of the Anatolian Greek population in the years 1922-1924.

\section{The pattern of Greek settlement in Asia Minor}

The Greek population of post-Byzantine Asia Minor through the exchange of Greek and Turkish populations in 1922-1923, could be distinguished ethnographically in three broad entities, on the basis of clearly identifiable geographical, cultural, sociological and linguistic characteristics. The first entity comprised the dense Greek settlements of the Western and North-Western coastal regions of the peninsula from the Sea of Marmara to the Kerme Gulf, extending inland along the riverine valleys of Western Asia Minor.

During the early centuries of the Turkish conquest, especially after the fall of Philadelphia (Alaşehir), the last Byzantine stronghold, in 1390, Greek presence was dramatically reduced in those hitherto demographically Greek-dominated regions ${ }^{3}$. Vestiges of Greek settlement could always be found both in the cities and in the countryside in the subsequent

3. See Speros Vryonis, Jr., The Decline of Medieval Hellenism in Asia Minor and the Process of Islamization from the Eleventh through the Fifteenth Century, Berkeley 1971, 133 ff., $145 \mathrm{ff}$., 244 ff.; Hélène Ahrweiler, "L'histoire et la géographie de la région de Smyrne entre les deux occupations Turques (1081-1317) particulièrement au XIII siècle», Byzance: les pays et les territoires, London, Variorum Reprints, 1976, IV, pp. 2-4, 7-11, 26-28. 
period ${ }^{4}$, but it was not until the eighteenth century and especially in the course of the nineteenth century, that the Greek presence in Western Asia Minor was steadily reinforced by migrations from the Aegean islands, the Peloponnese and continental Greece ${ }^{5}$. Smyrna and its region in particular became a great centre of attraction of Greek settlers, thus developing into a major Greek city in the Ottoman Empire. The migration process was curiously strengthened after the creation of the independent Greek state in the $1830 \mathrm{~s}^{6}$.

The origin of a great part of this section of Anatolian hellenism in migration from insular and continental Greece, proudly recalled by many Anatolian Greeks, and the geographical orientation of their new homelands towards the Aegean Sea explain their close ties with mainland hellenism as well as the preservation of common Modern Greek as their linguistic medium ${ }^{7}$. It might therefore be observed that after the critical reduction in numbers brought about by the Turkish conquest, the eighteenth and nineteenth centuries witnessed the reenactment of the ancient migration pattern that had produced Aeolian and Ionian hellenism in the archaic and classical periods ${ }^{8}$. With Smyrna as its metropolis and the coastal and inland cities of Western Asia Minor as its epicentres, this Greek population experienced great economic and cultural boom during the second half of the nineteenth century ${ }^{9}$. The phenomenon was closely connected with the economic development experienced by the major sea ports of the Ottoman Empire after the Anglo-Ottoman treaty of com-

4. For the pertinent evidence see $\mathrm{O}$. Bärkan, «Essai sur les données statistiques», esp. p. 20: Table I.

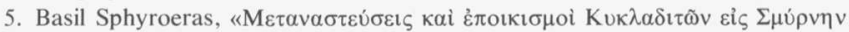

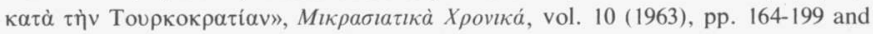

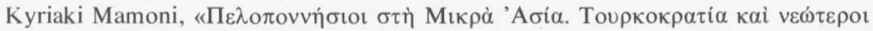

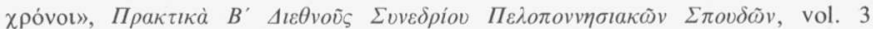
(1981-1982), pp. 209-224.

6. According to A. W. Kinglake, Eothen or Traces of Travel brought Home from the East, London 1844 , p. 74 , there are indications that such a migratory movement was already taking place as early as 1835 .

7. With the exception of a few Armenian speaking Orthodox villages in Bithynia in Northwestern Anatolia (Nicomedia/Brussa). There were also some scattered Turcophone Orthodox communities. See R. M. Dawkins, Modern Greek in Asia Minor, Cambridge 1916, pp. 37-38.

8. Cf. Michel B. Sakellariou, La migration grecque en Ionie, Athens 1958.

9. A. J. Panayotopoulos, «On the economic activities of the Anatolian Greeks»,

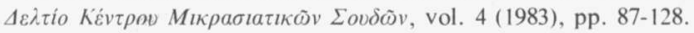


merce of 1838. As a consequence, the major European ports of the Empire, Constantinople and Thessaloniki, Smyrna and Kydonies (Ayvalik) on the Aegean coast of Asia Minor, Mersin, Attaleia and Alexandretta on the Mediterranean coast, Trebizond, Samsun and Sinope on the Black Sea coast developed into busy ports of European trade. The development of the port cities created needs in manpower and accordingly Christians from the rural areas in the interior of Asia Minor as well as from the Balkans were encouraged to migrate in order to fill the requirements of the labour force. Thus in addition to Christian migrants from the Aegean and mainland Greece, many rural migrants from the Christian villages of Cappadocia emigrated to Constantinople and Smyrna ${ }^{10}$. The many sided development of the Greek communities of the region greatly impressed all foreign observers of the area in that period and nurtured the political and national aspirations of the unredeemed Greeks of the Ottoman Empire ${ }^{11}$. Sociologically this section of Anatolian hellenism was the most urban and economically modernised, although its greatest proportion, especially in Northwestern Asia Minor, was overwhelmingly rural.

The second ethnographic entity of Asia Minor hellenism comprised the Orthodox Christian populations of the interior of the peninsula, which were dispersed over a vast geographical area enclosed by the network of the great rivers of Asia Minor: to the east of the fertile riverine valleys of the Aegean region, to the south of the rivers flowing into the Black Sea (Kizl . Irmak and Sakarya), to the west of the region of the sources of Tigris and Euphrates. Isolated by mountain ranges, deserts and plateaux on all sides, bordering to the east on the vastness of the Asiatic continent, this region had its only outlets to the south, where the valleys of the Taurus mountains and of the highlands along the Mediterranean coast, provide throughways to the sea.

The physical shape of this area constitutes a classic case of the decisive impact of the geographical factor on collective life in Mediterranean society, that has been argued so vividly by Fernand Braudel. In the hin-

10. Centre for Asia Minor Studies, MSS. nos. 24 / Cappadocia 26 (I. Kou-

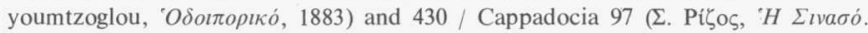

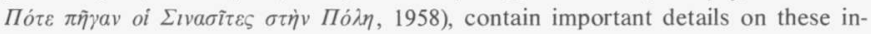
ternal migrations of Asia Minor Greeks.

11. See among many pertinent sources W. M. Ramsay, Impressions of Turkey during Twelve Years' Wanderings, London 1897, pp. 130-134, 252-257 and Karl Dietrich. Hellenism in Asia Minor, London 1918 (originally published under the title, Das Griechentum Kleinasiens, Leipzig 1915). 
terland of Anatolia the presence, location and natural formation of mountain masses determined, to a considerable extent, the collective destiny of local populations. This is made plain by the survival of Christian populations from Byzantine times to the twentieth century in the isolation of the mountain valleys of central Anatolia. Thus the natural features of the region turned it into a closed and self-contained world which preserved over time the essential characteristics of its social cohesion and cultural particularity ${ }^{12}$.

In the area of central and southern Anatolia the Christian Orthodox presence in modern times was quantitatively meagre but historically significant and ethnographically uniquely interesting. If the dense Greek settlements of the western regions of the peninsula had been by and large the product of relatively recent immigration, the sparce Orthodox communities, Greek speaking or Turkish speaking, of the interior of Asia Minor, constituted direct survivals from the medieval Byzantine presence in the region. The most incontrovertible sign of the Byzantine origin of the local population, especially in Cappadocia and Lycaonia, was offered by the highly peculiar Greek idioms spoken in some of those communities, which bore unmistakable resemblance to Medieval Greek despite the heavy Turkish influence, especially in diction ${ }^{13}$. Geographical isolation and the cutting off of these Christian communities to the east of the confrontation line between Byzantines and Turks in Asia Minor during the centuries of Turkish conquest (eleventh to fifteenth centuries), spared them the physical extinction or the cultural absorption through Islamization, which had wiped out most of the medieval Christian population of the peninsula ${ }^{14}$.

In the midst of the compact mass of Muslim population, the Christian

12. Fernand Braudel, The Mediterranean and the Mediterranean World in the Age of Philip II, New York 1972, vol. I, pp. 25-28, 162-167. The CAMS in researching Anatolian hellenism paid from the outset particular attention to geogra-

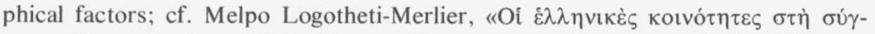

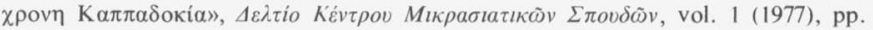
33-41.

13. R. M. Dawkins, Modern Greek in Asia Minor, p. 198, on the impact of Turkish on the Cappadocian Greek dialects: «the body has remained Greek but the soul has become Turkish».

14. Cf. Vryonis, The Decline of Medieval Hellenism, pp. $130 \mathrm{f} ., 155 \mathrm{f}$. For the Turkish conquest of Cappadocia see also Claude Cahen, «La première pénétration turque en Asie Mineure», Turcobyzantina et Oriens Christianus, London, Variorum Reprints, 1974, I, pp. 25-27, 31-33. 
element constituted a minority, which under the pressure of the conquest and of the exigencies of social survival had substituted Turkish for Greek as its language. The adoption of the language of their conquerors by the subject people was a mechanism of survival through the partial integration of the Turkish speaking Christians into local society ${ }^{15}$. The collective identity and the cultural particularity of the minority nevertheless was secured and preserved by the Orthodox Church. Orthodoxy became the hallmark of identity and the framework of collective consciousness. In the bosom of that Turcophone Christian society survived a few scattered and isolated linguistic islands, where Greek was preserved in the local idioms. These islets of Greek language were located in Makri and Livisi on the Lycian coast, in Sille near Konya in Lycaonia and especially in thirty two Grecophone out of the eighty one Orthodox communities in Cappadocia ${ }^{16}$.

Pontic hellenism formed the third ethnographic component of Greek presence in Anatolia. This ancient section of hellenism, with its lively recollections of its Byzantine splendour and its traditions of resistance, occupied the northern region of the peninsula, extending from the mouth of the Sakarya river along the Black Sea coast to the edge of the Caucasus. Pontic Greek communities penetrated into the highlands and valleys of the Pontic Alps and onto the southern slopes of that mountain range. Pontic presence further inland in central Anatolia, especially in Cappado-

15. Vryonis, The Decline of Medieval Hellenism, pp. 459-462. Cf. also Em-

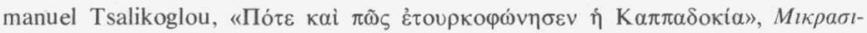

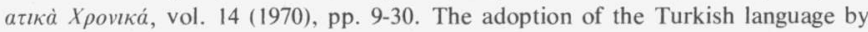
the Cappadocian Christians contributed to the emergence of the Karamanli literature, i.e. the publication of turcophone texts printed in the Greek alphabet, mainly for the fulfilment of the religious needs of the Turkish-speaking Orthodox. For details see the valuable work of S. Salaville and E. Dallegio, Karamanlidika. Bibliographie analytique d'ouvrages en langue turque imprimés en caractères grecs, Athens 1958-1966-1974, vol. I (1584-1850), vol. II (1851-1865) and vol. III (1866-1900). The Centre for Asia Minor Studies is at the moment publishing the fourth volume of the series, covering the period 1901-1929 and a volume of addenda to the three first volumes.

16. Cf. Dawkins, Modern Greek in Asia Minor, pp. 1-38. The local Greek idioms of Cappadocia constituted the object of systematic linguistic research undertaken by the CAMS. See N. Andriotis, Tò $\gamma \lambda \omega \sigma \sigma l \kappa \dot{o} i \delta i \omega \mu \alpha \tau \tilde{\omega} v \Phi \alpha \rho \alpha \dot{\sigma} \sigma \omega v$, Athens

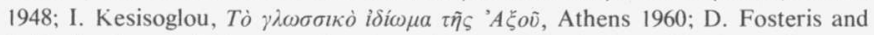

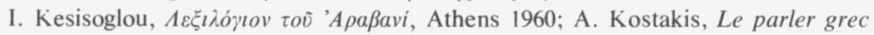
d'Anakou, Athens 1964. 
cia, was the product of the migration of mining communities from their base in the region of Argyroupolis (Gümüşhane) to other areas where their skills were in demand. Fortified by geographic isolation and its medieval state, the empire of the Grand Comneni of Trebizond, which was the last bastion of Byzantine hellenism to fall to the Turks in 1461, Greek society in the Pontos managed to preserve its social cohesion and ethnic continuity. The medieval Pontic empire had safeguarded local hellenism from the disruption and large-scale Islamization experienced by the rest of Anatolia during the five centuries of Byzantine-Turkish confrontation. In the Pontos the conquest came late and local Greek society was delivered intact and entrenched in its mountain strongholds to the new dynasts. The most incontrovertible evidence of its ethnological vigour was the preservation of its archaic language, a genuinely Greek though highly peculiar and idiomatic dialect. The Pontos was the foremost area where linguistic continuity transmitted uninterrupted the ancient Hellenistic and Byzantine cultural heritage of the area ${ }^{17}$. Thus Pontic Greek society preserved on a quantitatively larger scale the same feature of Byzantine survival as the Greek speaking villages of Cappadocia.

In its isolation and self-containment Pontic society constituted a whole Greek world on its own, which, after meeting successfully the challenges of conquest and survival, capitalised on the economic opportunities of the nineteenth century and achieved remarkable material prosperity and cultural progress ${ }^{18}$. The Greek population in the Pontos was primarily rural, living in the highlands of the region where the structure and cultural traditions of a closed, tightly knit society sealed it off from the outside world. In the course of the nineteenth century, the overland trade of the Middle East and Central Asia which used the Pontic port cities as its terminal points prior to the opening of the Suez canal, and the exploi-

17. Cf. Vryonis, The Decline of Medieval Hellenism, pp. 160-162, 446 f.; Anthony Bryer, "The Turkokratia in the Pontos: Some Problems and Preliminary Conclusions», The Empire of Trebizond and the Pontos, London, Variorum Re-

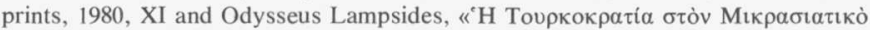

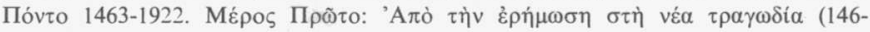

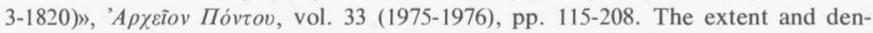
sity of Byzantine settlements in the region is now made plain by the evidence presented in Anthony Bryer and David Winfield, The Byzantine Monuments and Topography of the Pontos, Washington, D.C. 1985, vols. I-II.

18. Cf. Antony Bryer, "The Pontic Revival and the New Greece», The Empire of Trebizond and the Pontos, XII, pp. 189-190. 
TABLE I

\section{GREEK ORTHODOX SETTLEMENTS IN ASIA MINOR}

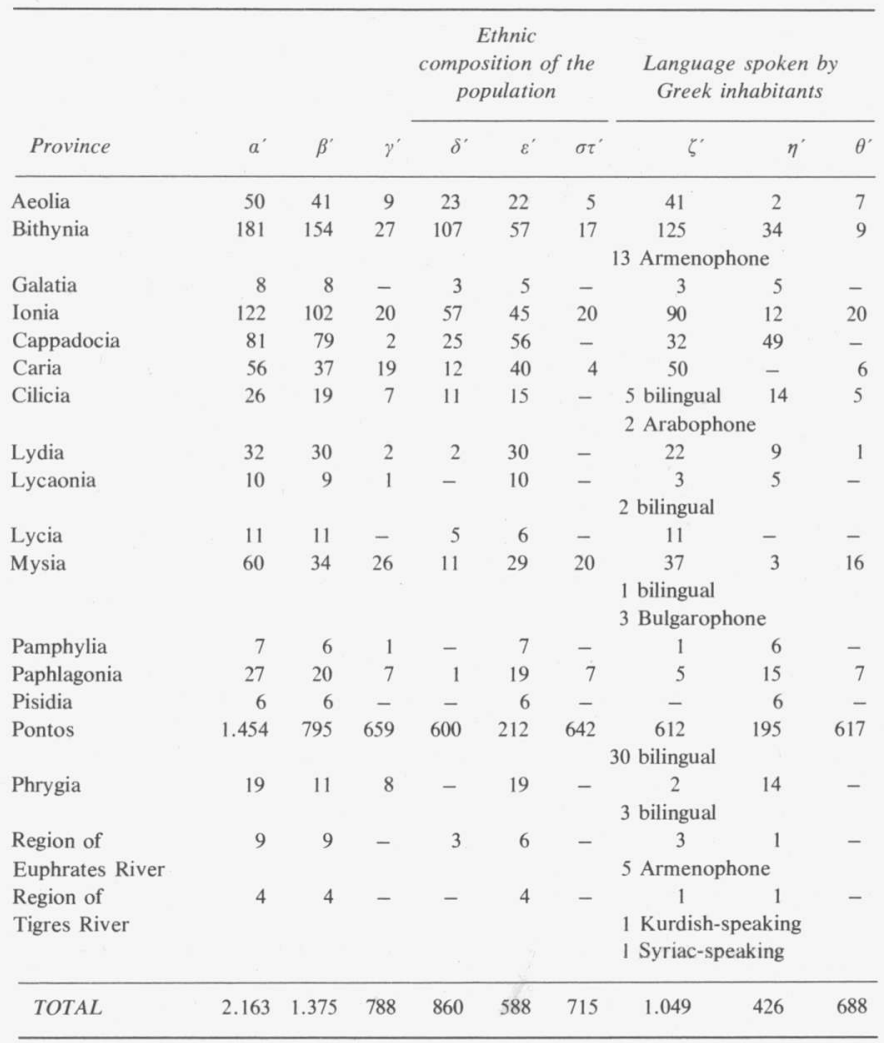

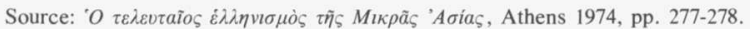

$\alpha^{\prime}: N^{o}$ of Greek settlements. $\beta^{\prime}: \mathrm{N}^{0}$ of settlements researched by CAMS. $\gamma^{\prime}: \mathrm{N}^{0}$ of settlements non researched. $\delta^{\prime}$ : Purely Greek settlements. $\varepsilon^{\prime}$ : Mixed Greek-Turkish settlements. $\sigma \tau^{\prime}$ : No information. $\zeta^{\prime}$ : Greek. $\eta^{\prime}$ : Turkish. $\theta^{\prime}$ : No information. 
tation of the natural resources of the area, contributed to economic and social changes that resulted in the creation of an important urban stratum in Pontic society, especially in such cities as Trebizond, Samsun and Sinope. This group provided the leadership of Pontic society, which spearheaded the local nationalist movement and the abortive attempt to create the republic of the Pontos in 1919-192219.

The quantative dimension of the Greek ethnography of Asia Minor is presented in Table I. The data have been collected over many decades of research by the Centre for Asia Minor Studies (CAMS) ${ }^{20}$. They present a picture of the geographical dispersion, the density of settlement patterns and the linguistic situation of the Orthodox Christian population of the peninsula at the beginning of the third decade of the twentieth century. The data are arranged geographically on the basis of the ancient Roman administrative division of the peninsula as it had evolved during the last third of the second century and the first half of the first century B.C.

This system of geographical classification has been followed by the Centre in its research on the model of contemporary Western archeological and historical literature on Asia Minor ${ }^{21}$. The table presents very graphically the density of Greek presence in the Pontos. It is by far the area of the highest concentration of Greek settlements, in which furthermore the Greek language was in use. Greek presence is attested in 1454

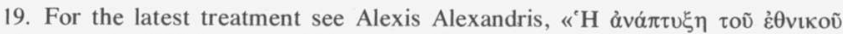

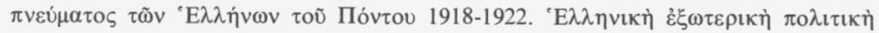

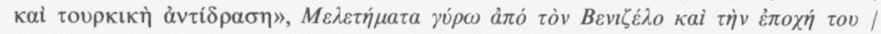
Studies on Venizelos and his time, ed. by O. Dimitrakopoulos and Th. Veremis, Athens 1980, pp. 427-474.

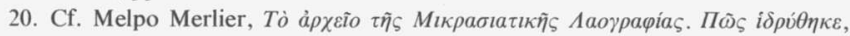

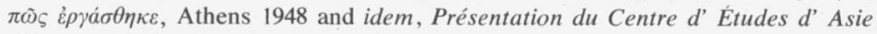

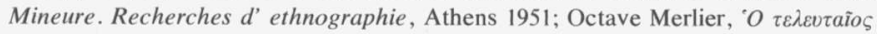

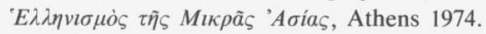

21. See e.g. the monumental works, Monumenta Asiae Minoris Antiqua, Manchester 1962, vols. I-VIII and Marcell Restle, Die byzantinische Wandmalerei in Kleinasien, Rechlinghausen 1967, vols. I-III, which present respectively the ancient Greek inscriptions and the Byzantine wall paintings of Asia Minor. The Centre for Asia Minor Studies adopted this method of geographical classification after a serious consideration of the historical character of the pertinent research issues. On this methodological logic see M. B. Sakellariou, Tà öpta $\tau \tilde{\omega} v \chi \omega \rho \tilde{v} v \kappa a \grave{i}$

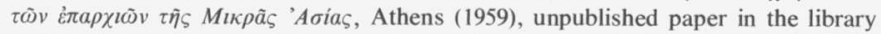
of the Centre. This work draws on D. Magie, Roman Rule in Asia Minor, Princeton 1950 , vols. I and II. 


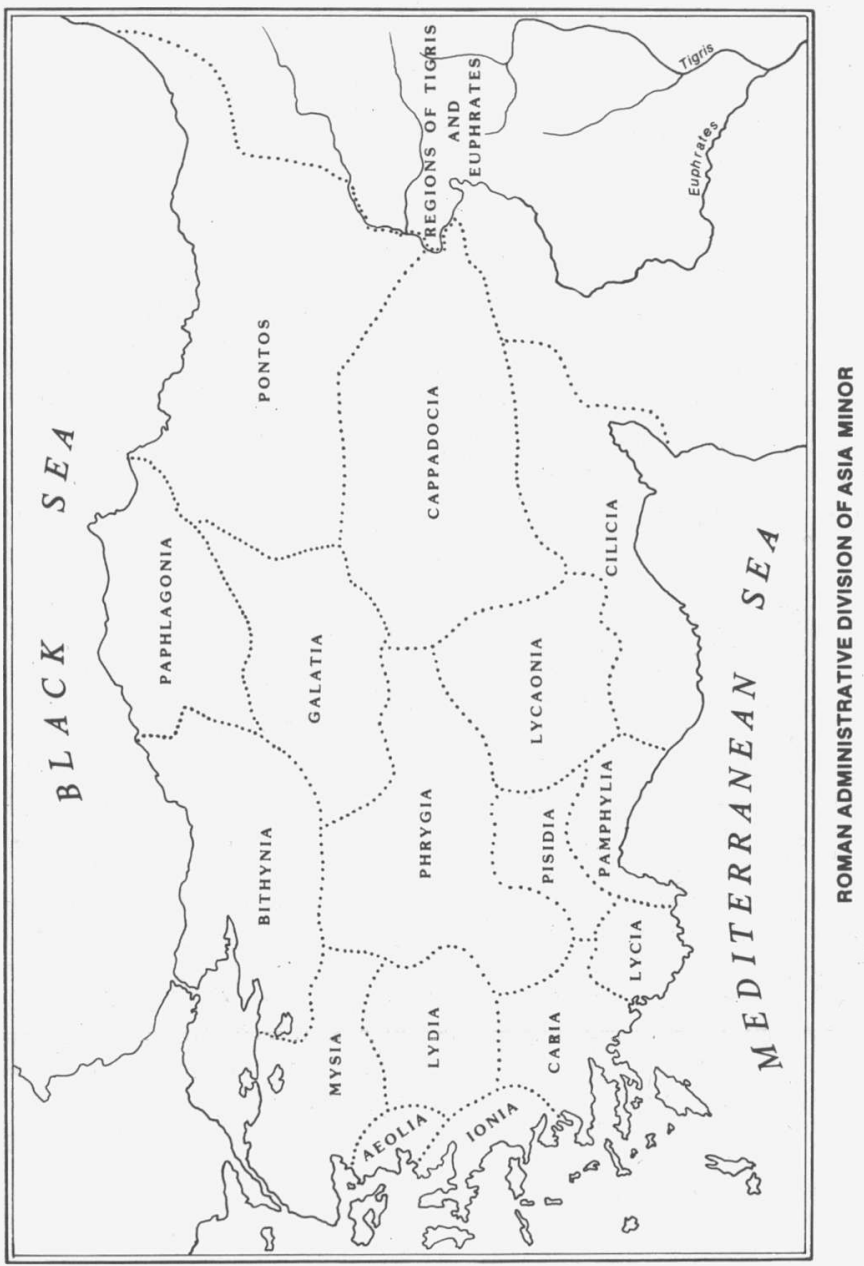


settlements of which 795 have been studied by the CAMS. Of these 600 were found to be entirely Greek, while 212 more were mixed Greek and Turkish villages. In 612 of these villages the inhabitants were Greekspeaking. A large number of settlements however (659) have remained unresearched for lack of native informants after the transfer of the Pontic population to Greece in 1924. This is explained by the fact that a large number of Pontic Greeks moved to the Caucasus and Southern Russia during the First World War and after the exchange of populations. Therefore the population of many Greek villages, especially from Eastern Pontos, never reached Greece. Next to the Pontic region the denser Greek settlement is encountered in Western and Northwestern Asia Minor in the provinces of Ionia (122 settlements) and Bithynia (181 settlements). In both of these provinces Greek predominated as the language of most settlements (in 90 out of 122 in Ionia and in 125 out of 181 in Bithynia). Cappadocia in central Asia Minor came fourth in density of Greek settlements with 81 villages and townships. In this area however, as in the rest of central and Southern Asia Minor, the linguistic pattern was reversed: the majority of the settlements were Turcophone (49 out of 81). In other provinces of the interior Turkish dominated completely as the language of the Orthodox population: thus in Pisidia all six Orthodox settlements spoke Turkish, in Phrygia 14 settlements out of 19 were entirely Turkish-speaking, in Pamphylia six out of seven were exclusively Turkishspeaking. The table shows that the linguistic picture was even more complicated than that. In Bithynia thirteen Orthodox villages were Armenian speaking as was the case in five out of nine Orthodox settlements in the region of the Euphrates river in Eastern Anatolia. In Cilicia two Orthodox villages spoke Arabic, in Mysia on the Asiatic coast of the Dardanelles three villages spoke Bulgarian while in the region of the Tigris river the four Orthodox villages spoke each Greek, Turkish, Kurdish and Syriac. To this pattern one must add the fact that many of the Greek speakers themselves spoke highly idiomatic and diverse dialects which made Greek speech quite incomprehensible from one region of Asia Minor to another and indeed from one Greek village to the next. We have already noted the uniqueness of Pontic Greek. In Cappadocia the picture of the local Greek idioms was even more complex with quite different dialects spoken in even neighbouring villages ${ }^{22}$. Only in Western Asia Minor and in major urban centres such as Constantinople and Smyrna, was standard Modern Greek in common use.

22. R. M. Dawkins, Modern Greek in Asia Minor, pp. 10-35. $62 \mathrm{ff}$. 
These details of linguistic diversity have been cited in order to put in perspective the enormous problems in communication and adaptation these people had to face after their compulsory transfer to Greece. Following the Ottoman tradition of the millet system, in determining the population groups subject to the compulsory exchange agreed upon at Lausanne in 1923, nationality was defined on the basis of religion rather than language ${ }^{23}$ and this meant the indiscriminate expulsion of both Greek and Turkish speaking Orthodox Christians from Asia Minor.

\section{The debate over numbers}

The controversy over the actual size of the Greek community in the Ottoman Empire is noted for its intensely political character. Although indispensable to Ottoman historical demography, ethnographic studies by Western observers in the nineteenth and early twentieth centuries, sutfer from many-sided biases and sometimes exemplify an appalling lack of information ${ }^{24}$. As a result contemporary statistical accounts of the Ottoman Greek millet tend to be mutually contradictory and therefore cannot be taken as comprehensive and substantive evidence ${ }^{25}$.

Recently a number of Turkish and American scholars tried to demonstrate that the Ottoman census system, particularly after the early 1880 s,

23. On the exchange of populations convention of 1923, see Stélio Séfériadès, «L' échange des populations», Académie de Droit International, Recueil des cours, vol. 4 (1928), pp. 311-437 and Th. Kiosseoglou, L' échange forcé des minorités d' après le Traité de Lausanne, Nancy 1926.

24. Even Vital Cuinet, La Turquie d' Asie, Paris 1892, which is widely cited as the best European source on Ottoman governmental statistics, did not escape major errors. Thus, in the subdivision of nationalities in Smyrna, his figures fell short of the total by 7.708 persons.

25. Characteristically, David Brewster writing in the first American edition (1832) of Edinburgh Encyclopaedia an article about Constantinople, remarks that «the population of Constantinople has been variously stated. Habesci makes it a million and a half, while Eton reduces it to less than 300.000 and Gallaway calculates it about 400.000 m. See also Vedat Eldem, Osmanlı Imparatorluğunun Iktisadi şartlar hakkında bir tetkik (A Study Relating to the Economic Conditions in the Ottoman Empire), Ankara 1970, pp. $49-59$ and Enver Ziya Karal, Osmanli Imparatorluğu'nda Ilk Nüfus Sayimi, 183I (The First Population Census of the Ottoman Empire, 1831), Ankara 1943. 
produced both accurate and comprehensive results ${ }^{26}$. This is a radically revisionist outlook on the hitherto widely held view of the unreliability of Ottoman census records. These efforts produced some valuable results in determining the size of the Ottoman Muslim population, though perhaps less so in calculating the exact proportion of the Greek community.

The difficulty inherent in any attempt to determine the numbers of the Ottoman Greeks is primarily connected with their tendency to avoid registering with Muslim civil authorities. Thus, even after the establishment of the Hamidian compulsory system of registration in 1881-1882, there is strong evidence indicating that the Greek community used records to show their numbers as low as possible so as to avoid military service and minimize their taxes ${ }^{27}$. Reluctance to register is well illustrated by the fact that as late as the 1920 s only some 30.000 Constantinopolitan Greeks had registered with the civil authorities and had received their Ottoman identity cards. The vexing question of the établis of 19231924 should be chiefly attributed to the non-registration of some 70.000 Istanbul Greeks with the Ottoman officials ${ }^{28}$.

In considering the Greek population of the Ottoman Empire historians cannot but consult the records of the Ecumenical Patriarchate and of local dioceses, now kept at the patriarchal archives at the Phanar. These include substantial collections of population data from each single Anatolian and Balkan Orthodox diocese ${ }^{29}$. It should be remembered that, in accordance with the millet system, it was with the patriarchal authorities rather than with the civil government that the Ottoman Greeks registered every birth, marriage, divorce, death and change of domicile (parish). The Greeks persisted in this practice, despite the centralising policies of the Hamidian and Young Turk regimes ${ }^{30}$.

26. Cf. Kemal H. Karpat, «Ottoman Population Records and the Census of $1881 / 82-1893$ », p. 240.

27. E.g. Richard Clogg, «Two Accounts of the Academy of Ayvalik (Kydonies), in 1818-1819», Revue des études sud-est européennes, vol. 10, no. 4 (1972), p. 652.

28. For details see Alexis Alexandris, The Greek Minority of Istanbul and Greek-Turkish Relations 1918-1974, Athens 1983, pp. 112-114.

29. The first concerted attempt by the Ecumenical Patriarchate to gather statistical population data on its flock took place in 1891 and continued with intervals until 1910-1912. A copy of the text of the Patriarchal encyclical addressed to all its dioceses in 1891 can be found in the Greek Foreign Ministry Archive (AYE) 1892/B50.

30. For the deep attachment of the Greek millet to its traditional socio- 
The historiographical problems associated with this behaviour have prompted Professor Kemal Karpat to maintain that «the birth, death and marriage registers supposedly kept by some Ottoman non-Muslim communities, to my knowledge, have never been unearthed». Another scholar, in his determination to prove that "there were in fact no usuable population records for the Ottoman Empire other than the Ottoman records", contented that "common sense should indicate to any researcher the unlikelihood of any army of Greek census-takers running across Anatolia and Thrace, counting all the inhabitants $\left.{ }^{32}\right\rangle$.

Yet research in the historical archive of the Greek Foreign Ministry has revealed substantive evidence that between 1910 and 1912 the Greek consular authorities in the Ottoman Empire, in close cooperation with the Greek Orthodox ecclesiastical authorities in Asia Minor and Thrace, carried out a detailed census of the Ottoman Greek population ${ }^{33}$.

The first attempt by the Greek Government to obtain statistical data on the Ottoman Greek Orthodox took place during the premiership of Stephen Dragoumis. Thus, on 21 June / 4 July 1910 Foreign Minister D. Kallergis addressed a note to all the Greek consular authorities in Asia Minor and European Turkey instructing them to conduct a census of the «Ottoman Greek nationals throughout Turkey» ${ }^{34}$. The census was to be

administrative privileges, see Alexandris, The Greek Minority of Istanbul, pp. 32-36.

31. Karpat, «Ottoman Population Records», p. 224.

32. Justin McCarthy, «Greek Statistics on the Ottoman Greek Population», International Journal of Turkish Studies, vol. 1, no. 2 (1980), pp. 66-76, at p. 72.

33. Until very recently the yields of the 1910-1912 census were scattered in various files, under different titles and varying dates. Most of the documents were placed in the files of the years 1919-1920. It was during this period that the yields of the census were widely consulted by Premier Eleftherios Venizelos as well as a number of Greek propagandists like D. Kalapothakis, George Soteriades, Leon Maccas, and D. N. Botzaris. In the course of the research for this paper and at the suggestion of Dr Domna Dontas, head of the historical archive of the Greek Foreign Ministry, all relevant documents were collected in separate files entitled «Greek Population Statistics» and are catalogued as AYE/B50 to B55/1910-1912. We hope to make available the yields of the entire census, together with the relevant correspondence between the Greek Foreign Ministry and the Greek consular authorities in the Ottoman Empire in a forthcoming publication of the Centre for Asia Minor Studies.

34. D. Kallergis to all the Greek consular authorities in the Ottoman Empire, no. 1652, 21 June / 4 July 1910, AYE/B50. 
conducted in close cooperation with Greek Orthodox ecclesiastical authorities in every district. Thus, mixed committees formed by consular employees and clerics would visit every single Greek or mixed village in Asia Minor and Thrace and get in touch with local notables, priests, doctors and teachers who in turn would furnish them with relevant statistical material $^{35}$. For the determination of the non-Greek population, the minister instructed them to base their data either on local information or on the Turkish salnames (yearbooks) ${ }^{36}$. Above all Kallergis stressed the sensitive nature of the undertaking and instructed them to discharge their task as discreetly as possible ${ }^{37}$.

With another note dated on 21 June 1910, the Consul-General in Istanbul, Constantine Kypraios, was instructed to form a central committee which was to direct and coordinate the whole enterprise. Soon after the Consul-General organised a team of experts which included a number of Ottoman Greeks, who had in the past served in the Ottoman civil service $^{38}$.

Meanwhile, responding favorably to an invitation by the Athens Government to assist in the conduct of the census, the Ecumenical Patriarchate instructed its dioceses in Asia Minor and in the Balkans to furnish the census-takers with all the necessary local records and statistical material ${ }^{39}$. To make sure that Greek census-takers would obtain from the local clergy the required data, representatives of Phanar were also included in the above-mentioned census committee ${ }^{40}$.

Finally, the census was taken on the basis of the following questionnaire ${ }^{41}$ :

35. ibid.

36. ibid. For a record of the salnames see Hasan Duman, ed, Osmanli Yilliklar, Istanbul 1982.

37. ibid.

38. The team of experts comprised Minas Chamoudopoulos, a senior official of the Sublime Porte and author of a geographical study on Asia Minor, George Scalieris, a member of the Ahrar party and the author of the influential study $L a$ décentralisation et la réforme administrative (Istanbul 1911), and the Karamanli Greek Vais Vaianos. G. Scalieris later published an important ethnological study of Asia Minor with important population data under the title Aaoi кai Фviai $\tau \tilde{\eta} \varsigma$

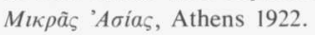

39. D. Kallergis to Patriarch Joachim III, no. 14134, 21 June / 4 July 1910 AYE/B50.

40. ibid.

41. Copy of the questionnaire in AYE 1910/B50. 


\section{ETHNIC SURVIVAL, NATIONALISM AND FORCED MIGRATION}

1. What is the name of the town or village that you inhabit?

2. To which ka za does it belong?

3. How many inhabitants does it have (men, women, children)?

4. How many Greek Orthodox are registered with the ecclesiastical authorities?

5. How many Turks reside in your town or village?

6. How many Armenians?

7. How many Jews?

8. How many of other nationalities?

9. What language do the Greek residents speak?

10. How many Greek Orthodox churches, chapels and monasteries do you have in your town or village?

11. How many Orthodox priests do you have?

12. How many of them are educated?

13. How many boys' schools do you have in your town or village?

14. How many girls' schools?

15. How many classes does each of them have?

16. What is the number of teachers employed in each of them?

17. What is the expenditure of the schools in your town or village?

18. How many missionary schools do you have in your district?

19. How many Greeks study in missionary schools?

20. How many Turkish schools do you have in your town or village?

21. How many Greeks study in them?

22. What other additional information can you give us?

The questionnaire was also communicated by the Patriarchate to all the heads of the Greek Orthodox dioceses in Asia Minor and European Turkey. Table II shows the thirty two dioceses in Asia Minor and the Aegean islands contacted by the Phanar. These dioceses geographically cover the whole of the Anatolian peninsula and therefore the census conducted through them can be considered as a full-scale survey of the entire Greek Orthodox population of Asia Minor.

The necessity of conducting an accurate and purely Greek census in Asia Minor and European Turkey was given top priority by Eleftherios Venizelos after his election as prime minister of Greece in 191042. On October 31, 1910, the Greek foreign minister, John Griparis, despatched

42. Eleftherios Venizelos became prime minister on 19 October / 1 November 1910 and remained in power until 10/23 March 1915. 
TABLE II

GREEK ORTHODOX DIOCESES OF ASIA MINOR AND THE AEGEAN ISLANDS INSTRUCTED BY THE ECUMENICAL PATRIARCHATE TO ASSIST THE GREEK CONSULAR AUTHORITIES IN THE CENSUS OF 1910-1912*

1. Smyrna (Izmir)

2. Krini (Çeşme)

3. Ilioupolis (Aydın)

4. Pisidia (Antalya)

5. Philadelphia (Alaşehir)

6. Ephesus (Efes/Selçuk)

7. Prussa (Bursa)

8. Nicaea (Iznik)

9. Chalcedon (Kadıköy)

10. Nicomedia (Izmit)

11. Cyzicus/Dardanelles (Erdek/Çanakkale)

12. Kydoniai/Moschonisa (Ayvalık)

13. Proikonisos (Marmara)

14. Amaseia (Amasya)

15. Angyra (Ankara)

16. Ikonion (Konya)
17. Caesarea (Kayseri)

18. Rhodopolis (Maçka)

19. Chaldia (Gümüşhane)

20. Trebizond (Trabzon)

21. Kolonia (Sabinkarahisar)

22. Neocaesarea (Niksar)

23. Imbros (Gökçeada)

24. Mitylene

25. Chios

26. Samos

27. Lemnos

28. Karpathos

29. Kalymnos

30. Rhodos

31. Mythimna

32. Patmos

* Statistical data for the Greek population of European Turkey can also be found in the Greek Foreign Ministry Archives.

another note to the Greek consular authorities in the Ottoman Empire asking them to expedite the census ${ }^{43}$. The task, however, was a collossal one. The consular reports on the conduct of the census contain many details on the difficulties encountered in the organisation of the undertaking and the collection of the data ${ }^{44}$. Particularly difficult to surpass was the suspicious nature of the Greek villagers, who in many instances shied away from registering even with the Greek Orthodox ecclesiastical authorities fearing that the Ottoman civil authorities might get hold of the records and use them as evidence to increase their taxes or draft them to

43. John Griparis to all the Greek consular authorities in the Ottoman Empire, no. 14555, AYE/B50.

44. The consul in Smyrna complained that the notables of the Greek villages in the area of Mentechorion (Menteşe) refused to cooperate with the consular/ecclesiastical authorities; T. Mikes to J. Griparis, Smyrna, no. 450, 14 / 27 February 1912, AYE/B50. Others complained about the indifferent attitude adopted by some of the senior clergy in their districts; M. Sgouros to Greek Foreign Ministry, Kydoniai (Ayvalik), no. 350, 2 / 15 February 1912, AYE/B55. 
the army ${ }^{45}$. Nor did the vastness of the area under the jurisdiction of the few Greek consuls in Asia Minor render their task any easier. It is quite clear that almost no consul was able to furnish statistical material on any but the Ottoman Greek population.

In calculating the non-Greek populations, the more enterprising amongst them relied exclusively on contemporary salnames while the majority in their replies did not include any information on the other millets. Predictably the census concentrated solely on the Ottoman Greeks and has no practical value in the determination of the other racial, linguistic and religious groups of the empire.

By the beginning of 1913, the Greek Government was able to have a full-fledged statistical report on the Ottoman Greek population of Asia

TABLE III

GREEK POPULATION OF THE ANATOLIAN DIOCESES ACCORDING TO THE YIELDS OF 1910-1912 CENSUS

\begin{tabular}{lcc}
\hline Ecclesiastical name of Diocese & Ottoman Vilayet & Total \\
\hline Chalcedon (Kadıköy) & (Istanbul/Asia) & 128.850 \\
Smyrna (Izmir) & (Aydın) & 244.600 \\
Krini (Çeşme) & (Aydın) & 45.495 \\
Ilioupolis (Aydın) & (Aydın) & 37.595 \\
Ephesos (Selçuk) & (Aydın) & 143.342 \\
Kydoniai (Ayvalık) & (Aydın) & 10.000 \\
Philadelphia (Alaşehir) & (Aydın) & 14.904 \\
Pisidia (Antalya, Isparta) & (Konya) & 42.215 \\
Ikonion (Konya) & (Konya) & 90.300 \\
Prussa (Bursa) & (Hüdavendigâr) & 48.135 \\
Nicaea (Iznik) & (Hüdavendigâr) & 59.300 \\
Cyzicus/Dardanelles (Erdek/Çanakkale) & (Biga) & 109.950 \\
Proikonisos (Marmara) & (Biga) & 30.000 \\
Nicomedia & (Izmit) & 60.860 \\
Angyra & (Ankara) & 16.700 \\
Caesarea (Kayseri) & (Ankara) & 65.120 \\
Amaseia (Amasya) & (Sivas) & 123.398 \\
Neocaesarea (Niksar) & (Sivas) & 102.563 \\
Kolonia (Sabinkarahisar) & (Sivas) & 36.530 \\
Trebizond & (Trabzon) & 60.564 \\
Chaldia (Gümüşhane) & (Trabzon) & 60.669 \\
Rhodopolis (Maçka) & (Trabzon) & 16.862 \\
\hline & &
\end{tabular}

45. P. Adamidis to the Foreign Minister, Samsun, no. 477, $6 / 19$ December 1910, AYE/B50. 
Minor and European Turkey. As it is shown in Table III, the Greek population of the western, southwestern, north and northeastern provinces of Asia Minor was just over 1.5 million. The Ottoman Greeks of Southeastern (Cilicia) and Eastern (Erzurum) Asia Minor, who belonged to the Patriarchate of Antioch were not included in the census. Similarly, the flourishing Greek communities of Eastern Thrace are also excluded from this table. Two samples of the findings of the census from two different areas of Asia Minor are given in Tables VI and VII in Appendices A and $B$ respectively. Appendix A presents the census data for the diocese of Amaseia on the Black Sea coast of Western Pontos while Appendix B presents the educational census data for the diocese of Krini on the Çeşme peninsula on the western coast of Asia Minor, across the channel from the island of Chios.

On the basis of the evidence discussed in the foregoing account, the controversial and politically charged issue of the Greek census of 19101912 can now be viewed in an entirely new light. The yields of this census were used in 1919 by many Greek political figures in order to

TABLE IV

COMPARATIVE STATISTICAL TABLE OF ANATOLIAN GREEK POPULATION

\begin{tabular}{|c|c|c|c|}
\hline & $\begin{array}{l}\text { Kitromilides/ } \\
\text { Alexandris* }\end{array}$ & McCarthy tables & Polybius tables \\
\hline Istanbul Asia & 189.710 & 85.250 & 149.470 \\
\hline $\begin{array}{l}\text { Aydın } \\
\text { Konya }\end{array}$ & 495.936 & 319.020 & 629.002 \\
\hline $\begin{array}{l}\text { Hüdavendigâr } \\
\text { Biga } \\
\text { Ankara }\end{array}$ & 379.900 & 288.371 & 388.850 \\
\hline $\begin{array}{l}\text { Sivas } \\
\text { Trabzon } \\
\text { Kastamonu }\end{array}$ & 482.406 & 408.576 & 521.814 \\
\hline TOTAL & 1.547 .952 & 1.101 .217 & 1.777 .146 \\
\hline
\end{tabular}

* The Greek Orthodox ecclesiastical dioceses in Anatolia were not identical to Ottoman provincial units (vilayets). As a result of the overlappings this table has lumped together neighbouring Ottoman administrative divisions. 
promote their foreign policy claims ${ }^{46}$. As a consequence, the whole issue was entagled in political propaganda and this has led scholars unsympathetic to Greek claims to question the very existence of the census itself. The absence of any such Greek census, in turn, would have made the discrepancies between the yields of 1910-1912, when the Greeks were still peacefully living in Asia Minor, and those of 1924-1928, which recorded the refugee population of Greece, less glaring.

In light of this new empirical evidence some basic issues in the historical demography of Asia Minor in the closing decades of the Ottoman Empire must be reconsidered. Specifically the quantitative dimensions of Greek presence in Asia Minor can now be appraised on the basis of the new census data and therefore the uncertainty about its numerical magnitude, nurtured by politically motivated claims and counter-claims, can be replaced with an empirically verifiable picture. Table IV attempts to place this new picture in comparative perspective by juxtaposing the data of the 1910-1912 patriarchal census (Kitromilides-Alexandris) to the figures cited by critics who have disputed the very taking of that census (McCarthy) and finally to the population numbers advanced by spokesmen of Greek claims in Asia Minor at the end of World War I (Polybius $)^{47}$. The table suggests that the thesis that there was no Greek census, also involves a radical underestimation of the actual size of the Greek Orthodox population in Asia Minor, reducing it on the whole by slightly more than 28 per cent. On the other hand, the population magnitudes on which Greek claims were based after 1918 as presented by Polybius, appear to be inflated, in comparison to the actual numbers record-

46. N. Petsalis-Diomidis, Greece at the Paris Peace Conference (1919), Thessaloniki 1978, pp. 172-200, 228-250, 318-338 and especially Appendix A in ibid., pp. 341-347 on population statistics and sources. It should be noted that at the Paris Peace Conference it was a common practice to produce statistical data that enhanced the demographic presence of one or the other ethnic element. This practice was not followed just by Venizelos, but also by the representatives of the Ottoman Government as well as by the Armenian, Kurdish and Arab nationalist organizations. Nor was the practice of number-boosting at the Peace Conference limited to the Near East question. It was, in fact, a common phenomenon in all territorial disputes that emerged with the redrawing of the political map of Europe, following the end of World War I (Fiume, German-Polish, German-French, Polish-Russian, Serbo-Bulgarian disputes).

47. Polybius, Greece before the conference, foreword by T.P.O' Connor, M.P., London 1919, pp. 43-63 and 109-120. 
ed by the Greek census of $1910-1912$, by only 14.8 per cent. It can be concluded therefore that the statistical error contingent on the denial of the existence of a Greek census is higher by almost one hundred per cent in comparison with the numbers on which Greek claims were based in 1918.

\section{Forms of Exodus}

The differences in the conditions of collective existence of the three sections of Anatolian hellenism, were reflected as well in the form taken by the exodus of the Greek population of Asia Minor from their ancestral hearths. In the Western regions the civilian population found themselves in the theatre of war between Greece and Turkey (1919-1922) and consequently they paid a terrible toll in blood and death. Violent expulsion, accompanied by large scale massacres and other atrocities, provided the content of exodus from Western Asia Minor with the burning of Smyrna on September 11, 1922 as the symbol of the tragedy ${ }^{48}$. Thus the Greek population was violently expelled or massacred in Western Asia Minor in the early weeks of the autumn of 1922, well before the signing of the Lausanne Convention on the exchange of populations. Those who escaped the massacres flooded the Greek islands of the Eastern Aegean and then were transferred to the mainland, creating an immense refugee problem $^{49}$.

In the interior things worked out differently. News of the exchange did not reach the communities of Cappadocia until late in 1923 and the

48. Cf. the classic study of Marjorie Housepian, The Smyrna Affair, New

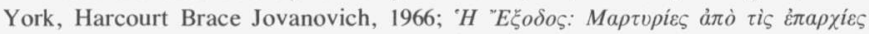

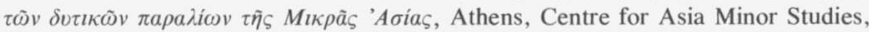
1980; Michael Llewellyn Smith, Ionian Vision: Greece in Asia Minor 1919-1922, London, Allen Lane, 1973, pp. 284-311. On the destruction of Smyrna see also

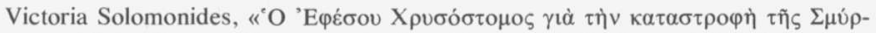

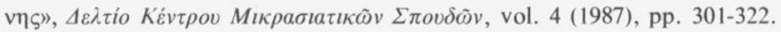

49. On the refugee problem in Greece see Henry Morgenthau, I was sent in Athens, Garden City, N. Y., 1929; Eliot G. Mears, Greece Today: The Aftermath of the Refugee Impact, Stanford 1929; C. B. Eddy, Greece and the Greek Refugees, London 1931; Stephen P. Ladas, The Exchange of Minorities. Bulgaria, Greece and Turkey, New York 1932; and especially the definitive study by D. Pentzopoulos, The Balkan Exchange of Minorities and its Impact upon Greece, Paris 1962. 
exodus was not completed until well into 1924. The Christian population of the Anatolian hinterland had been subjected to persecution and psychological violence intermittently since 1914 . The most serious hardship inflicted upon them was the conscription of the male population or the forced relocation of the Christians of many villages which meant exile to unhospitable and unknown places of Eastern Asia Minor. Massacres however, on the scale of those that occurred in the Western regions, were generally avoided. Thus the uprooting of the Greeks from the Anatolian hinterland was carried out peacefully and this allowed the local people to disengage gradually from their native land and to carry with them their precious relics, their community records and part of their movable property. For many of these people of the hinterland the compulsory expulsion involved their first journey away from the confines of their native village. In the context of this journey they saw the sea for the first time and experienced the pains of involuntary geographical mobility. Many died on the way. The gravest part of their adventure however came with the resettlement in Greece and the conditions of their absorption in Greek society ${ }^{50}$.

The form of exodus was further differentiated in the Pontos. The character of local Greek society, its cohesion, density and collective memories provided the sociological and psychological substratum to the resistance put up by the Pontic Greeks to the application of the Lausanne Convention. In many villages of the Pontic highlands armed groups of Pontic fighters attempted to resist the terrible fate that was imposed on them from outside. When it became clear that their resistance was in vain, the Pontic highlanders did not submit but they guided their communities into the neighbouring areas of the Caucasus to await their return. This was the last dramatic act of the Pontic tradition of resistance to outside pressures, made possible by the ethnological vigour of a society which could be disrupted and subdued only by overpowering external force $^{51}$.

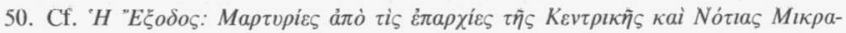
oias, Athens: Centre for Asia Minor Studies, 1982. On the exchange of the Greeks of Cappadocia see also Alexis Alexandris, «H ḋंó $\pi \varepsilon \iota \rho \alpha \delta \eta \mu \nu \rho \gamma i \alpha \varsigma$

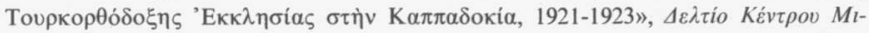

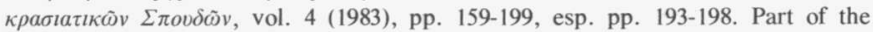
records of the mixed commission which supervised the evacuation of the Christian population of Cappadocia is included in the X. Mandanakis files, which are deposited in the Archive of the Centre for Asia Minor Studies.

51. The CAMS will publish a selection of testimonies from the exodus of Pon- 
A final aspect of the movement of Greek refugees from Turkey following the Lausanne Convention, involved the evacuation of the Greek population of Eastern Thrace. This region was ceded to Greece as sovereign territory by the Treaty of Sèvres in 1920. Ethnically it was the only region of Turkey in which the combined Greek and Bulgarian elements formed a clear majority in the population ${ }^{52}$. Both in the plain of Eastern Thrace and in the coastal cities on the Black Sea and the Sea of Marmara the Greek element, rural and urban, formed the most lively and productive component of the local population and by all accounts shaped the character of the region. In the early twentieth century the numbers of the Greeks were rising very fast due to their economic prosperity, which was also reflected in the increasing density of the network of their cultural and educational institutions in the area ${ }^{53}$. Another important indication of the increase of Greek population in Eastern Thrace in the early twentieth century was the multiplication of the dioceses of the Ecumenical Patriarchate in the region at the period ${ }^{54}$. Thrace was occupied by Greek forces in 1919 and remained untouched by the rage of the Greek-Turkish war in Asia Minor during the following three years. Thus in the fall of 1922 the Greek army in Thrace was the only Greek force on the front that had not suffered defeat and was quite capable and

tos in "E stantinople 1922-1923: The Human Cost of the Exchange of Populations», 'A $\rho$ -

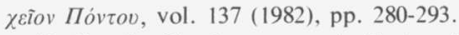

52. For the Greek presence in Eastern Thrace see A. Antoniades, Le róle économique des Grecs en Thrace. Rapport soumis à la conference de la paix le 27

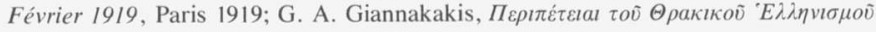
à̃ò $\tau \dot{o}$ 1904-1922, Athens 1955.

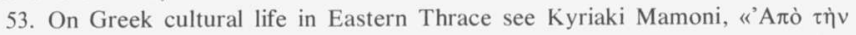

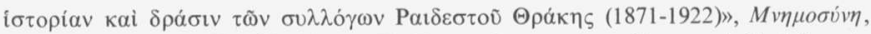

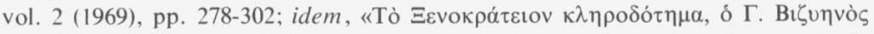

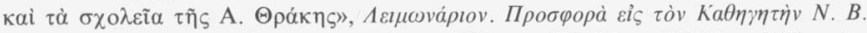

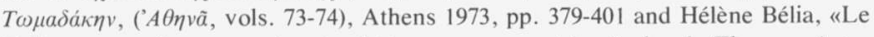
Syllogue pour la propagation des lettres grecques» et les écoles de Thrace», Actes du $I I^{\mathrm{c}}$ Congrès International des Etudes du Sud-Est Européen (1970), vol. IV, Athens 1978, pp. 369-376.

54. This development is reflected in the election of new bishops as indicated by the official registers of the Ecumenical Patriarchate. For the period 1878-1924 see

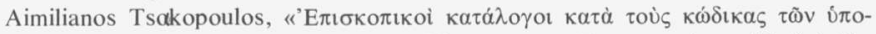

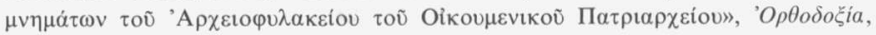
vol. 33 (1958), pp. 150-173, 281-304, 395-426 and vol. 34 (1959), pp. 12-35. 
prepared to put up resistance to the threatened Turkish advance into the area. This option however was rejected by the Greek government and the Greek army was ordered to withdraw from Eastern Thrace to the Evros river in October $1922^{55}$. Before pulling out of the region however, the Greek forces provided a shield for the peaceful evacuation of the Greek population of Eastern Thrace. The Thracian Greeks were thus spared the massacres and violence suffered by the Anatolian Greeks. Mounted on their oxen-drawn carts or on foot they took the road to exile in Greece. They. kept crossing the Evros river for weeks in the late fall of 1922 in a process of uprooting of really epic proportions ${ }^{56}$. With the evacuation of Eastern Thrace the Greek presence in the new Turkey was limited to Istanbul and the islands of Imbros (Gökçeada) and Tenedos (Bozcaada), which were also returned to Turkish sovereignty by the Treaty of Lausanne ${ }^{57}$.

\author{
TABLE V
}

REFUGEE POPULATION OF GREECE (1928)

\begin{tabular}{lr}
\hline $\begin{array}{l}\text { Asia Minor: } \\
\quad \text { Ionia, Cappadocia etc.) }\end{array}$ & 626.954 (of which 35.000 of \\
Pontos: & 182.169 \\
Constantinople: & $\underline{38.459}$ \\
$\quad$ Total & 847.582 \\
Eastern Thrace: & 256.635 \\
$\quad$ Grand Total of Refugees & $\underline{\underline{1.104 .217}}$ \\
\hline
\end{tabular}

Source: Statistical Annual of Greece, Athens 1930, p. 41.

55. See Harry J. Psomiades, The Eastern Question. The Last Phase, Thessaloniki 1968, pp. 39-50.

56. The events were described by, among others, Ernest Hemingway, who was a correspondent for Toronto Star in the Near East. See David Walder, The Chanak Affair, London 1969.

57. For the subsequent history see Alexandris, The Greek Minority of Istanbul and Greek-Turkish Relations, and idem, «Imbros and Tenedos: A Study in Turkish Attitudes Toward Two Ethnic Greek Island Communities Since 1923», Journal of the Hellenic Diaspora, vol. 7, no. 1 (1980), pp. 5-31. The recent book 
The numerical strength of the Anatolian and Thracian refugee population which flooded into Greece after 1922, was not established until the general population census, taken in Greece on May 5,1928. As indicated in Table $\mathrm{V}$ the Total refugee population of Greece was 1.104.217 persons, of whom 626.954 came from Asia Minor, including 35.000 of Armenian origin. An additional 182.169 persons came from the Pontos region, 256.635 from Eastern Thrace and 38.459 from Istanbul. The numbers in Table V present the refugees found in Greece in 1928 and do not take account of deaths and emigration from Greece between 1922 and 1928. It has been estimated that about 75.000 persons died as a result of natural mortality between 1922 and 1928. Similarly about 66.000 Greeks from Asia Minor did not go to Greece, or if they initially fled to Greece, soon reemigrated to Western Europe, the United States or Egypt ${ }^{58}$. Finally it is estimated that about 80.000 Pontic Greeks instead of going to Greece prefered to take refuge in the Caucasus and Southern Russia, continuing an old pattern of migration from Pontos into those regions ${ }^{59}$.

These figures total up to 1.325 .217 persons as the entire refugee population which was expelled from both Asia Minor and Eastern Thrace after 1922. This sum total however is still lower than the number of 1.547.952 persons of Greek Orthodox origin estimated in 1910-1912 as living in Asia Minor alone. If the numbers for Eastern Thrace and Istanbul are subtracted from the totals a very grim picture indeed will emerge concerning the fate of the Greek Orthodox population of Asia Minor. Out of a total of 1.547 .952 persons in 1912, after a decade of war, violence and exile only an estimated 847.954 persons had survived and managed to take refuge in Greece and other lands. The macabre gap between these two numbers makes plain the human drama behind the debates on the historical demography of the last decade of the Ottoman Empire. The cold numerical magnitudes involved in this debate dramatise in their own silent way the cost in blood and death brought about as a consequence of nationalist confrontation, war and the forcible expulsion of populations from their ancestral homelands.

PASCHALIS M. KITROMILIDES - ALEXIS ALEXANDRIS

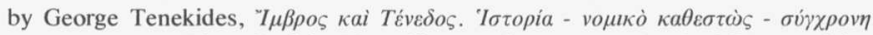
$\pi \rho \alpha \gamma \mu \alpha \tau \kappa$ ó $\eta \tau \alpha$, Thessaloniki 1986, offers an important record of human rights violations on the two islands.

58. See Justin McCarthy, Muslims and Minorites: The Population of Ottoman Anatolia at the End of the Empire, New York 1983, pp. 130-133.

59. See Bryer, "The Pontic Revival and the New Greece», p. 189. 


\section{APPENDIX A}

TABLE VI

GREEK POPULATION OF THE DIOCESE OF AMASEIA*

\begin{tabular}{|c|c|c|c|c|c|c|c|}
\hline$a^{\prime}$ & $\beta^{\prime}$ & $\gamma^{\prime}$ & $\delta^{\prime}$ & $\varepsilon^{\prime}$ & $\sigma \tau^{\prime}$ & $\zeta$ & $\eta^{\prime}$ \\
\hline 1. Amisos & Samsun & Canik & 8.618 & Greek & 1 & 3 & 3 \\
\hline 2. Upper Amisos & " & " & 1.870 & " & 2 & - & 2 \\
\hline 3. Atatepe & " & " & 470 & " & 1 & - & 1 \\
\hline 4. Ulugöl & " & " & 165 & " & 1 & - & 1 \\
\hline 5. Papaz Mahalesi & » & 》 & 570 & " & 2 & - & 1 \\
\hline 6. Pelitoğlu & " & $"$ & 320 & " & 2 & - & 1 \\
\hline 7. Misali Tuz & " & " & 214 & " & 1 & - & 1 \\
\hline 8. Haydar & " & $"$ & 167 & " & 2 & - & 1 \\
\hline 9. Göl Bellen & " & " & 420 & " & 2 & - & 1 \\
\hline 10. Yegile Giriş & " & $"$ & 285 & " & 1 & - & 1 \\
\hline 11. Seyminanto & » & $"$ & 305 & " & 1 & - & 1 \\
\hline 12. Demirciköy & " & $n$ & 125 & " & 1 & - & 1 \\
\hline 13. Simitçi & $»$ & " & 180 & » & 1 & - & 1 \\
\hline 14. Karamahmur & $"$ & $"$ & 175 & " & 1 & - & 1 \\
\hline 15. Kızıloglak & » & " & 200 & » & 1 & - & 1 \\
\hline 16. Maradon & $»$ & $n$ & 153 & " & 1 & - & 1 \\
\hline 17. Kelkaya & " & " & 253 & " & 1 & - & 1 \\
\hline 18. Zigadon & " & ” & 178 & » & 1 & - & 1 \\
\hline 19. Karagöl & " & $"$ & 673 & " & 4 & - & 2 \\
\hline 20. Panayot Uşağı & $»$ & $"$ & 327 & $»$ & 1 & - & 1 \\
\hline 21. Kurtalanı & » & " & 210 & " & 1 & - & 1 \\
\hline 22. Çinarlı & " & » & 500 & 》 & 1 & - & 1 \\
\hline 23. Serniç Dağı & " & " & 458 & 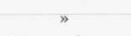 & 2 & - & 1 \\
\hline 24. Dev Giriş & $"$ & $"$ & 516 & Turcophone & 1 & - & 1 \\
\hline 25. Kürekçi & $»$ & " & 127 & Greek & 1 & - & 1 \\
\hline 26. Boylan & $»$ & " & 477 & Turcophone & 3 & - & 1 \\
\hline 27. Gürgen Pınarı & " & $"$ & 283 & $"$ & 2 & - & 1 \\
\hline 28. Kara Songur & » & $"$ & 319 & » & 3 & - & 1 \\
\hline
\end{tabular}

* The statistics carry the signature of consul Matlis and the date 16/29 December 1911, Samsun.

$a^{\prime}$ : Name of city or village. $\beta^{\prime}$ : Name of Kaza. $\gamma^{\prime}$ : Name of villayet. $\delta^{\prime}$ : Greek inhabitants. $\varepsilon^{\prime}$ : Language spoken by Greek-Orthodox. $\sigma \tau^{\prime}$ : Churches, chapels, monasteries. $\zeta^{\prime}$ : Orthodox priests educated. $\eta^{\prime}$ : Orthodox priests non educated. 


\begin{tabular}{|c|c|c|c|c|c|c|c|}
\hline$a^{\prime}$ & $\beta^{\prime}$ & $\gamma^{\prime}$ & $\delta^{\prime}$ & $\varepsilon^{\prime}$ & $\sigma \tau^{\prime}$ & $\zeta$ & $\eta^{\prime}$ \\
\hline 29. Taflan Köy & Samsun & Canik & 316 & Turcophone & 1 & - & 1 \\
\hline 30. Haci Ismail & " & " & 216 & Greek & 1 & - & 1 \\
\hline 31. Yarmalı Yatak & $"$ & " & 129 & $»$ & 1 & - & 1 \\
\hline 32. Elias Köy & $"$ & " & 380 & $»$ & 1 & - & 1 \\
\hline 33. Serniç Pınarı & " & " & 125 & Turcophone & 1 & - & 1 \\
\hline 34. Andreandon & $"$ & " & 1.180 & Greek & 2 & - & 2 \\
\hline 35. Terme & $"$ & » & 277 & Turcophone & 3 & - & 1 \\
\hline 36. Sogut & $"$ & " & 75 & " & - & - & $-*$ \\
\hline 37. Kara Percin & " & " & 1.308 & Greek & 1 & - & 2 \\
\hline 38. Çam Alanı & $"$ & " & 278 & $"$ & 1 & - & 1 \\
\hline 39. Çanakçı & $"$ & " & 370 & 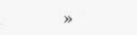 & 1 & - & 1 \\
\hline 40. Derecik & " & " & 391 & " & 1 & - & 1 \\
\hline 41. Çatalarmut & $"$ & " & 169 & " & 1 & - & 1 \\
\hline 42. Ata & » & $"$ & 340 & " & 1 & - & 1 \\
\hline 43. Çirakman & » & $"$ & 922 & " & 1 & - & 1 \\
\hline 44. Kabacık & 》 & 》 & 129 & $"$ & 1 & - & $-^{* *}$ \\
\hline 45. Düzeren & " & " & 278 & Turcophone & 1 & - & 1 \\
\hline 46. Çadır & ” & " & 190 & Greek & 1 & - & 1 \\
\hline 47. Narlık & " & $》$ & 250 & Greek & 1 & - & 1 \\
\hline 48. Hayat Deresi & ” & 》 & 407 & $"$ & 3 & - & 1 \\
\hline 49. Bellen & " & " & 570 & " & 2 & - & 1 \\
\hline 50. Toyar & » & " & 280 & $»$ & 3 & - & 1 \\
\hline 51. Elma Çukur & " & " & 793 & Turcophone & 4 & - & 1 \\
\hline 52. Topal Uşağı & » & " & 140 & " & 1 & - & 1 \\
\hline 53. Ömer Gölü & » & " & 376 & $"$ & 2 & - & 1 \\
\hline 54. Kalkacık & " & " & 66 & Greek & 1 & - & - \\
\hline 55. Gelice & » & " & 136 & $"$ & 1 & - & 1 \\
\hline 56. Karatoklu & " & " & 70 & $"$ & 1 & - & 1 \\
\hline 57. Soğanly & " & " & 103 & $"$ & 1 & - & - \\
\hline 58. Oca & " & " & 850 & $»$ & 2 & - & 1 \\
\hline 59. Erekli & $"$ & " & 198 & Turcophone & 4 & - & 1 \\
\hline 60. Akdogan & $"$ & $"$ & 122 & 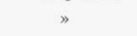 & 1 & - & 1 \\
\hline 61. Incebal & $"$ & » & 282 & " & 2 & - & 1 \\
\hline 62. Kaya Güney & " & " & 553 & " & 3 & - & 1 \\
\hline 63. Kuru Kökçü & " & » & 374 & " & 3 & - & 1 \\
\hline 64. Tepecik & » & » & 435 & Greek & 1 & - & 1 \\
\hline 65. Avtan & " & " & 230 & $»$ & 1 & - & 1 \\
\hline 66. Atulgan & " & " & 692 & " & 5 & - & 2 \\
\hline 67. Çardak Yeri & $»$ & $»$ & 243 & $»$ & 1 & - & 1 \\
\hline 68. Töbeçik & $"$ & $»$ & 410 & Turcophone & 1 & - & 1 \\
\hline 69. Sarı Boyur & " & $"$ & 207 & Greek & 2 & - & 1 \\
\hline 70. Futucak & » & » & 203 & " & 2 & - & 1 \\
\hline
\end{tabular}

* Unable to maintain a priest of their own they invite those of the neighbouring villages. ** Invite the priest of Derecık. 


\begin{tabular}{|c|c|c|c|c|c|c|c|}
\hline$a^{\prime}$ & $\beta^{\prime}$ & $\gamma^{\prime}$ & $\delta^{\prime}$ & $\varepsilon^{\prime}$ & $\sigma \tau^{\circ}$ & $\zeta^{\prime}$ & $\eta^{\prime}$ \\
\hline 71. Sarn Kilise & Samsun & Canik & 370 & Greek & 2 & - & 1 \\
\hline 72. Arucak & " & $"$ & 306 & $»$ & 1 & - & 1 \\
\hline 73. Moskovanton & » & $»$ & 91 & " & 1 & - & 1 \\
\hline 74. Mazinoglu & " & " & 123 & " & 1 & - & 1 \\
\hline 75. Kütekçi & " & $»$. & 113 & 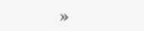 & 1 & - & 1 \\
\hline 76. Çiğıer & " & $"$ & 738 & Greek-Turkish & 6 & - & $3^{*}$ \\
\hline 77. Tangorlu & $»$ & " & 481 & Greek & 2 & - & 2 \\
\hline 78. Çarşamba** & Çarşamba & $"$ & 1.273 & Turcophone & 1 & - & 2 \\
\hline 79. Hisarlı & $"$ & » & 366 & $»$ & 1 & - & 1 \\
\hline 80. Koçalan & Samsun & " & 155 & Greek & 1 & - & 1 \\
\hline 81. Romanandon & " & " & 179 & $»$ & 1 & - & 1 \\
\hline 82. Kireçdere & $»$ & $"$ & 182 & Turcophone & 1 & - & 1 \\
\hline 83. Bohçaarmut & » & " & 236 & " & 1 & - & 1 \\
\hline 84. Kazancoğlu & Çarşamba & $"$ & 282 & $"$ & 1 & - & 1 \\
\hline 85. Çorluyeri & $"$ & " & 406 & " & 1 & - & 1 \\
\hline 86. Derviş Tekfur & $n$ & " & 158 & 》 & 1 & - & 1 \\
\hline 87. Dikenli Yatak & " & " & 250 & $"$ & 1 & - & 1 \\
\hline 88. Kamşi & " & $"$ & 229 & $"$ & 1 & - & 1 \\
\hline 89. Kirazh & " & " & 345 & Greek & 1 & - & 1 \\
\hline 90. San Yurt & " & " & 233 & $»$ & 1 & - & 1 \\
\hline 91. Yenice & " & " & 199 & Turcophone & 1 & - & 1 \\
\hline 92. Ordu Kapı & " & $"$ & 308 & " & 1 & - & 1 \\
\hline 93. Kamışlı Köy & Samsun & " & 118 & Greek & 1 & - & - \\
\hline 94. Yağ Basan & Çarşamba & $"$ & 336 & $»$ & 2 & - & 1 \\
\hline 95. (?Sum) Pinar & Samsun & " & 152 & » & 1 & - & - \\
\hline 96. Kışla & $»$ & " & 325 & » & 2 & - & 1 \\
\hline 97. Gedikli & " & $"$ & 121 & " & 1 & - & 1 \\
\hline 98. Firincioğlu & " & $"$ & 240 & " & 1 & - & 1 \\
\hline 99. Klimiandon & " & " & 301 & $»$ & 2 & - & 1 \\
\hline 100. Çal & " & " & 228 & " & & & \\
\hline 101. Kazlı Köy & " & " & 181 & " & 1 & - & 1 \\
\hline 102. Gövce Pinar & " & " & 276 & $"$ & 1 & - & 1 \\
\hline 103. Kaman & " & » & 123 & » & 1 & - & 1 \\
\hline 104. Gel Girişi & " & " & 160 & " & 1 & - & 1 \\
\hline 105. Sinamatas & $"$ & » & 278 & $"$ & 3 & - & 1 \\
\hline 106. Paşa Yiataği & " & " & 95 & $n$ & 1 & - & - \\
\hline 107. Gâvur Yurdu & " & " & 234 & " & 1 & - & 1 \\
\hline 108. Trabzonlu & " & " & 177 & $»$ & 1 & - & 1 \\
\hline 109. Upper Canik & * & » & 283 & ” & 1 & - & 1 \\
\hline 110. Lower Canik & $"$ & " & 1.115 & $"$ & 3 & - & 3 \\
\hline
\end{tabular}

* The village of Çigyer maintained 9 Mahales with 6 churches and 2 schools. The priests were bilingual and performed the sermons sometimes in Greek and at other times in Turkish.

** The town of Çarşamba was mainly inhabited by Turks (3.814). There were also 1.348 Turcophone Armenians. At Çarşamba was the seat of the Kaymakam. 


\begin{tabular}{|c|c|c|c|c|c|c|c|}
\hline$a^{\prime}$ & $\beta^{\prime}$ & $\gamma^{\prime}$ & $\delta$ & $\varepsilon^{\prime}$ & $\sigma \tau^{\prime}$ & $\zeta^{\prime}$ & $\eta^{\prime}$ \\
\hline 111. Gökçe & Samsun & Canik & 241 & Greek & 1 & - & 1 \\
\hline 112. Gürgenli & " & $"$ & 221 & $»$ & 1 & - & 1 \\
\hline 113. Alibey & » & ” & 270 & » & 1 & - & 1 \\
\hline 114. Düz Köy & " & $"$ & 1.130 & Turcophone & 2 & - & 1 \\
\hline 115. Kel Uşaği & " & " & 171 & " & 1 & - & 1 \\
\hline 116. Sogüt Pınarı & » & " & 335 & " & 1 & - & 1 \\
\hline 117. Kurv Gökçe & » & " & 320 & " & 1 & - & 1 \\
\hline 118. Kâzim Köy & » & $n$ & 409 & » & 1 & - & 1 \\
\hline \multicolumn{8}{|l|}{ 119. Kahvehane } \\
\hline Seyvani & " & $»$ & 230 & " & 1 & - & 1 \\
\hline 120. Amasya* & Amasya & Sivas & 1.300 & " & 1 & - & 1 \\
\hline 121. Ilerai & $»$ & $"$ & 38 & " & 1 & - & - \\
\hline 122. Tuzsuz & $»$ & $"$ & 320 & " & 1 & - & 1 \\
\hline 123. Zagana & " & " & 294 & » & 1 & - & 1 \\
\hline 124. Apacı & » & $»$ & 223 & » & 1 & - & 1 \\
\hline 125. Findikhı & » & » & 451 & " & 1 & - & 1 \\
\hline 126. Merzifun** & Merzifun & " & 475 & $"$ & 1 & - & 1 \\
\hline 127. Yedimköy & Amasya & " & 151 & " & 1 & - & 1 \\
\hline 128. Bayat & Corum & $"$ & 209 & " & 1 & - & 1 \\
\hline 129. Kelin (Sinisi?) & " & " & 155 & » & 1 & - & 1 \\
\hline 130. Mahmutlu & " & » & 197 & " & 1 & - & 1 \\
\hline 131. Osmancık & » & $"$ & 259 & " & 1 & - & 1 \\
\hline 132. Sirakeze (?) & Ladik & Canik & 478 & " & 1 & - & 1 \\
\hline 133. Kemal & Amasya & Sivas & 430 & " & i & - & 1 \\
\hline 134. Turasan & $"$ & $»$ & 209 & " & 1 & - & 1 \\
\hline 135. Hamam Ayaği & » & 》 & 287 & " & 1 & - & 1 \\
\hline 136. Iskilip & " & » & 391 & " & 1 & - & 1 \\
\hline 137. Doğanly & » & " & 153 & » & 1 & - & 1 \\
\hline 138. Karaova & " & » & 133 & » & 1 & - & 1 \\
\hline 139. Terzili & $»$ & » & 250 & " & 1 & - & 1 \\
\hline 140. Alayurt & Corum & " & 328 & " & & & \\
\hline 141. Üçsaray & Ladik & Canik & 182 & " & 2 & - & 1 \\
\hline 142. Karaaraç Pınarı & Amasya & Sivas & 178 & " & 1 & - & 1 \\
\hline 143. Kışla & " & $»$ & 175 & " & 1 & - & 1 \\
\hline 144. Tataroglu & " & 》 & 163 & » & 1 & - & 1 \\
\hline 145. Saharca & " & $"$ & 516 & " & 1 & - & 1 \\
\hline 146. Taşh Yarıca & » & ” & 321 & " & 3 & - & 1 \\
\hline 147. Choritsa (?) & " & " & 238 & " & 2 & - & 1 \\
\hline 148. Hacıalı & " & " & 226 & " & 1 & - & 1 \\
\hline 149. Kireçliköy & " & " & 180 & " & 2 & - & 1 \\
\hline 150. Hocaoglan & " & ” & 320 & » & 1 & - & 1 \\
\hline 151. Bellen Alaca & " & " & 225 & " & 1 & - & 1 \\
\hline
\end{tabular}

* According to the yields of the Greek census in the town of Amasya there were 15.000 Turks, 9.860 Armenians and 206 Protestants.

** At the town of Merzifun was the seat of Kaymakam. 


\begin{tabular}{|c|c|c|c|c|c|c|c|c|}
\hline$a^{\prime}$ & $\beta^{\prime}$ & $\gamma^{\prime}$ & $\delta^{\prime}$ & $\varepsilon^{\prime}$ & $\sigma \tau^{\prime}$ & $\zeta^{\prime}$ & & $\eta^{\prime}$ \\
\hline 152. Çamurköy & Amasya & Sivas & 161 & " & & 1 & - & 1 \\
\hline 153. Havza* & Havza & " & 293 & " & & 1 & - & 1 \\
\hline 154. Ali Efendi Çifliği & Amasya & $»$ & 92 & " & & 1 & - & 1 \\
\hline 155. Erik Alan & » & " & 257 & " & & 1 & - & 1 \\
\hline 156. Narlık & » & $»$ & 177 & " & & 1 & - & 1 \\
\hline 157. Çeltek & » & ” & 45 & " & & - & - & - \\
\hline 158. Ağturasan & 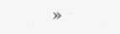 & 》 & 335 & " & & 1 & - & 1 \\
\hline 157. Kara Misir & » & " & 193 & * & & 1 & - & 1 \\
\hline 158. Göz(ruf?) & » & " & 906 & $"$ & & 2 & - & 2 \\
\hline 159. Yağbasan & " & " & 348 & $"$ & & 1 & - & 1 \\
\hline 160. Koçoğlu & $"$ & » & 923 & $»$ & & 2 & - & 1 \\
\hline 161. Eskigören & $"$ & " & 102 & $»$ & & 1 & - & 1 \\
\hline 162. Kenek & " & » & 136 & $\gg$ & & 1 & - & 1 \\
\hline 163. Karaçörek & $n$ & " & 224 & $"$ & & 1 & - & 1 \\
\hline 164. Çiǧköy & $"$ & * & 257 & $»$ & & 1 & - & 1 \\
\hline 165. Hacidede & $"$ & $"$ & 175 & $»$ & & 1 & - & 1 \\
\hline 166. Çayıroğlu & $"$ & " & 420 & $»$ & & 1 & - & 1 \\
\hline 167. Kovanites & " & » & 143 & $»$ & & 1 & - & 1 \\
\hline 168. Aydoğdu & $"$ & " & 307 & $"$ & & 2 & - & 1 \\
\hline 169. Seferli & $"$ & $"$ & 166 & $»$ & & 1 & - & 1 \\
\hline 170. Yahna & $"$ & $"$ & 285 & $»$ & & 2 & - & 1 \\
\hline 171. Taşoluk & $"$ & $"$ & 54 & 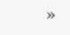 & & - & - & - \\
\hline 172. Efkaliptus & $"$ & $"$ & 278 & $»$ & & 1 & - & 1 \\
\hline 173. Domuzalan & » & " & 247 & $»$ & & 1 & - & 1 \\
\hline 174. Orfano & " & " & 347 & $»$ & & 2 & - & 1 \\
\hline 175. Dere(cen?) & " & » & 236 & $»$ & & 2 & - & 1 \\
\hline 176. Burcuk Alan & " & " & 159 & $»$ & & 1 & - & 1 \\
\hline 177. Emirçik & " & " & 359 & $"$ & & 1 & - & 1 \\
\hline 178. Göbeçay & " & " & 115 & $"$ & & 1 & - & 1 \\
\hline 179. Girenlik & " & " & 154 & $»$ & & 1 & - & 1 \\
\hline 180. Havacık & $"$ & $"$ & 387 & $"$ & & 1 & - & 1 \\
\hline 181. Ahyurt & $"$ & $"$ & 72 & $"$ & & 1 & - & - \\
\hline 182. Oktaş & " & » & 250 & 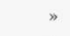 & & & & \\
\hline 183. Doluca & » & " & 120 & $"$ & & 1 & - & 1 \\
\hline 184. Kızıl Çörek & » & ” & 125 & $"$ & & 1 & - & 1 \\
\hline 185. Yağcı Mahmut & $"$ & 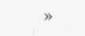 & 125 & ” & & 1 & - & 1 \\
\hline 186. Dikenli & Vezirköprü & " & 110 & $"$ & & 1 & - & 1 \\
\hline 187. Gözüm Aran & Amasya & » & 109 & $"$ & & - & - & - \\
\hline 188. Turna Göl & " & " & 88 & $"$ & & 1 & - & - \\
\hline 189. Cepni & » & 》 & 287 & $"$ & & 2 & - & 1 \\
\hline 190. Dereköy & " & » & 707 & $"$ & & 1 & - & 1 \\
\hline 191. (?)Yohça Armut & 》 & " & 169 & " & & 1 & - & 1 \\
\hline 192. Karaklı & " & $"$ & 398 & » & & 3 & - & 1 \\
\hline
\end{tabular}

* In this town there were 2.076 Turks and 235 Armenians. 


\begin{tabular}{|c|c|c|c|c|c|c|c|}
\hline$a^{\prime}$ & $\beta^{\prime}$ & $\gamma^{\prime}$ & $\delta^{\prime}$ & $\varepsilon^{\prime}$ & $\sigma \tau^{\prime}$ & $\zeta$ & $\eta^{\prime}$ \\
\hline \multicolumn{8}{|l|}{ 193. Vezirköy/ } \\
\hline Vezirköprü* & Vezirköprü & $"$ & 225 & * & 1 & - & 1 \\
\hline 194. Içerli & ” & ” & 184 & » & 1 & - & 1 \\
\hline 195. Erencik & " & $"$ & 666 & " & 1 & - & 1 \\
\hline 196. Saraycık & » & " & 492 & » & 1 & - & 1 \\
\hline 197. Kaya Alan & $»$ & $"$ & 70 & " & 1 & - & 1 \\
\hline 198. Kaplan & Amasya & " & 304 & » & 1 & - & 1 \\
\hline 199. Süleyman Köy & " & $"$ & 415 & » & 1 & - & 1 \\
\hline 200. Bacas & ; & " & 249 & » & 1 & - & 1 \\
\hline 201. Bucuk Çifligi & » & $»$ & 405 & $»$ & 1 & - & 1 \\
\hline 202. Kocas & $»$ & $"$ & 353 & " & 2 & - & 1 \\
\hline 203. Haci Yurt & 》 & $"$ & 182 & » & 1 & - & 1 \\
\hline 204. Uluca Alan & " & " & 269 & » & 1 & - & 1 \\
\hline 205. Alan & " & " & 581 & » & 1 & - & 1 \\
\hline 206. Harman (Tokath?) & Vezirköprü & " & 678 & " & 3 & - & 1 \\
\hline 207. Mermer Altı & Amasya & " & 325 & , & 1 & - & 1 \\
\hline 208. Ilica & " & * & 154 & " & 1 & - & 1 \\
\hline 209. (?)Bel Karakum & " & " & 284 & » & 1 & - & 1 \\
\hline 210. Kireçlik & $»$ & $"$ & 444 & " & 1 & - & - \\
\hline 211. Agaçlık & » & " & 120 & " & 2 & - & 1 \\
\hline 212. Kavaklıca & " & " & 110 & » & - & - & - \\
\hline 213. Bey Alan & » & " & 449 & » & - & - & - \\
\hline 214. Katır Alan & " & " & 505 & » & 1 & - & 1 \\
\hline 215. Tepeköy & " & " & 361 & " & 2 & - & 1 \\
\hline 216. Hacı Giriş & " & " & 436 & ·" & 2 & - & 1 \\
\hline 217. Kara Pinar & * & " & 225 & » & 2 & - & 1 \\
\hline 218. Kızlar Alan & $»$ & $»$ & 145 & $n$ & 2 & - & 1 \\
\hline 219. Büyük & Samsun & Canik & 128 & $"$ & 1 & - & 1 \\
\hline 220. Kaz Çayir & Amasya & Sivas & 217 & $"$ & 2 & - & 1 \\
\hline 221. Biçiçik & " & $"$ & 174 & " & 2 & - & 1 \\
\hline 222. Kavak & Samsun & Canik & 258 & " & 3 & - & - \\
\hline 223. Gölüce Ağaç & Amasya & Sivas & 340 & " & 1 & - & 1 \\
\hline 224. Yilan Gören & " & $\gg$ & 187 & $"$ & 1 & - & 1 \\
\hline 225. Tekneçik & Samsun & Canik & 397 & " & 1 & - & 1 \\
\hline 226. Karaçam & $»$ & $»$ & 646 & $"$ & 1 & - & 1 \\
\hline 227. Zogoli & » & " & 330 & " & 2 & - & 1 \\
\hline 228. Karadağ & » & » & 390 & " & 3 & - & 1 \\
\hline 229. Serniç & " & " & 660 & $"$ & 3 & - & 1 \\
\hline 230. Sinop** & Sinop & Kastamonu & 3.668 & Greek & 4 & 2 & 2 \\
\hline 231. Profitis Ilias & $»$ & $"$ & 590 & " & 1 & - & 1 \\
\hline 232. Karacaköy & » & $\bowtie$ & 269 & " & 1 & 1 & \\
\hline 233. Yukarı Köy & " & 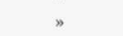 & 493 & " & 1 & - & 1 \\
\hline 234. Derviş Yeri & » & » & 218 & » & 1 & - & 1 \\
\hline
\end{tabular}

* In Vezirköy the yields of the census give also 7.800 Turks and 880 Armenians.

** In Sinop there were also some 3.000 Muslim Turkish inhabitants. 


\begin{tabular}{|c|c|c|c|c|c|c|c|}
\hline$a^{\prime}$ & $\beta^{\prime}$ & $\gamma^{\prime}$ & $\delta^{\prime}$ & $\varepsilon^{\prime}$ & $\sigma \tau^{\prime}$ & $\zeta$ & $\eta^{\prime}$ \\
\hline 235. (Hertza?) Ger7e* & Sinop & Kastamonu & 645 & » & 1 & $»$ & 1 \\
\hline 236. Domuz Alan* & " & " & 306 & " & 1 & - & 1 \\
\hline 237. Mortza & " & " & 341 & Turcophone & 1 & - & 1 \\
\hline 238. Kasapcı & " & " & 93 & $"$ & 1 & - & - \\
\hline 239. Fiarna & " & " & 121 & " & 1 & - & 1 \\
\hline 240. (Taïsta?) Tosya & » & " & 386 & » & & & \\
\hline 241. Ayiancık & $"$ & " & 93 & " & 1 & - & 1 \\
\hline 242. Tosos & » & " & 266 & » & 1 & - & 1 \\
\hline 243. Bafra & Bafra* & " & 2.822 & 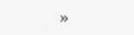 & 1 & - & 3 \\
\hline 244. Leloukler & $"$ & * & 231 & » & 1 & - & 1 \\
\hline 245. Pehni Uşaği & Samsun & Canik & 425 & 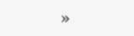 & 2 & - & 1 \\
\hline 246. Devre & » & $"$ & 475 & » & 1 & - & 1 \\
\hline 247. Darbogaz & » & " & 317 & » & 1 & - & 1 \\
\hline 248. Duğurlar & " & " & 416 & » & 1 & - & 1 \\
\hline 249. Karaca (Direk?) & " & " & 166 & » & 2 & - & 1 \\
\hline 250. Ölcekler & " & " & 188 & $\Rightarrow$ & 1 & - & 1 \\
\hline 251. Otmasa & " & " & 191 & " & 1 & - & 1 \\
\hline 252. Ağaca & " & » & 393 & " & 2 & - & 1 \\
\hline 253. Kireçli & " & » & 537 & " & 3 & - & 1 \\
\hline 254. Asmaçam . & " & " & 528 & $"$ & 2 & - & 1 \\
\hline 255. Köşecik & " & » & 458 & » & 1 & - & 1 \\
\hline 256. Yermen Uşağı & " & " & 227 & » & 1 & - & 1 \\
\hline 257. Tepecik & 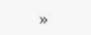 & » & 472 & , & 2 & - & 1 \\
\hline 258. Çanakli & " & " & 672 & $"$ & 3 & - & 1 \\
\hline 259. Beytorlu & ” & " & 169 & $»$ & 3 & - & 1 \\
\hline 260. Ormanos & $"$ & " & 775 & $"$ & 1 & - & - \\
\hline 261. Yavlanos & " & " & 154 & $"$ & 2 & - & 1 \\
\hline 266. Domuzoğlu & " & " & 590 & $"$ & 2 & - & - \\
\hline 267. Değirmen Küney & " & » & 242 & " & 2 & - & 1 \\
\hline 268. Keller & " & » & 313 & " & 1 & - & 1 \\
\hline 269. Karagözoğlu & " & $»$ & 180 & $"$ & 1 & - & 1 \\
\hline 270. Cantar & " & $»$ & 121 & $"$ & 1 & - & 1 \\
\hline 271. Yalıtepe & » & $»$ & 88 & " & 1 & - & - \\
\hline 272. Sürmeli & " & » & 320 & " & 1 & - & - \\
\hline 273. Evrak Uşağı & " & » & 212 & " & 2 & - & 1 \\
\hline 274. Dolan Ova & » & » & 318 & " & 1 & - & 1 \\
\hline 275. Kaytalapa (?) & » & » & 315 & " & 1 & - & - \\
\hline 276. Yangeli Yatak & » & $»$ & 142 & " & 1 & - & - \\
\hline 277. Çıplaklar & " & » & 177 & " & 1 & - & - \\
\hline
\end{tabular}

* With a population of 5.000 Turks the Greeks were only a small minority in the mixed village of Hertza.

** Bafra, the seat of the Kaymakam, was a mixed town with 3.871 Muslim Turks and 1.372 others, mainly Armenians. 


\begin{tabular}{|c|c|c|c|c|c|c|c|}
\hline$a^{\prime}$ & $\beta^{\prime}$ & $\gamma^{\prime}$ & $\delta$ & $\varepsilon^{\prime}$ & $\sigma \tau^{\prime}$ & $\zeta^{\prime}$ & $\eta^{\prime}$ \\
\hline 278. Osmanoğlu & Samsun & Canik & 420 & Turcophone & 1 & - & 1 \\
\hline 279. Muzmelek & " & $"$ & 280 & " & 1 & - & 1 \\
\hline 280. Beykeller & " & $"$ & 397 & " & 2 & - & 1 \\
\hline 281. Papazpınar & ” & $"$ & 383 & $»$ & 1 & - & 1 \\
\hline 282. Balıklar & " & $"$ & 297 & " & 1 & - & 1 \\
\hline 283. Pire Gördü & ” & " & 321 & 》 & 1 & - & 1 \\
\hline 284. Chrisoköy & " & » & 582 & " & 2 & - & 1 \\
\hline 285. Sirkeciköy & " & $"$ & 328 & $»$ & 2 & - & 1 \\
\hline 286. Sihlik & " & $"$ & 548 & 》 & 3 & - & - \\
\hline 287. Kabaçakır & » & " & 297 & $"$ & 2 & - & 1 \\
\hline 288. Yayla & $»$ & " & 579 & $"$ & 3 & - & 1 \\
\hline 289. Kaya Pinar & » & » & 257 & " & 1 & - & 1 \\
\hline 290. Ulu Soyut & " & " & 224 & 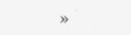 & 1 & - & 1 \\
\hline 291. Ulu Köy & ” & " & 162 & " & 1 & - & 1 \\
\hline 292. Mayili & $»$ & " & 184 & » & 1 & - & - \\
\hline 293. Domuzağa & » & " & 132 & $"$ & 3 & - & 1 \\
\hline 294. Gürlü Domuz & " & $"$ & 242 & " & 1 & - & 1 \\
\hline 295. Arab Ocağı & » & " & 146 & " & 1 & - & 1 \\
\hline 296. Zeynel & " & $n$ & 341 & " & 2 & - & - \\
\hline 297. Selami & " & $"$ & 327 & " & 1 & - & 1 \\
\hline 298. Köşe Mahale & » & " & 245 & » & 1 & - & 1 \\
\hline 299. Elmacık & " & $"$ & 646 & » & 1 & - & 1 \\
\hline 300. Erikcik & 》 & $"$ & 167 & » & 2 & - & 1 \\
\hline 301. (?) Boy & " & " & 846 & $»$ & 1 & - & - \\
\hline 302. Koca Su & " & $»$ & 332 & $»$ & 2 & - & 1 \\
\hline 303. Aktepe & 》 & " & 1.011 & " & 2 & - & 1 \\
\hline 304. Tokath & ” & " & 280 & " & 1 & - & 1 \\
\hline 305. Kuyutepe & 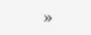 & " & 82 & » & 1 & - & 1 \\
\hline 306. (Egiz?) Tepe & ” & " & 107 & " & 1 & - & 1 \\
\hline 307. Koçer & " & » & 434 & $\gg$ & 1 & - & 1 \\
\hline 308. Koğal(uce?) & ” & " & 341 & " & 1 & - & 1 \\
\hline 309. Kato Astir & " & $"$ & 532 & 》 & 1 & - & 1 \\
\hline 310. Ano Astir & ” & " & 650 & " & 1 & - & 1 \\
\hline 311. Kapı Kaya & ” & $"$ & 834 & » & 1 & - & 1 \\
\hline 312. Kato Alan & " & $"$ & 466 & " & 1 & - & 1 \\
\hline 313. Hatır Alexandro & $»$ & " & 130 & » & 1 & - & 1 \\
\hline 314. Muamerli & " & $"$ & 245 & » & 1 & - & 1 \\
\hline 315. Konstandi Usağı & » & $"$ & 304 & » & 1 & - & 1 \\
\hline 316. Arpa & » & " & 331 & " & 1 & - & 1 \\
\hline 317. Tazıl & " & " & 207 & " & 1 & - & - \\
\hline 318. Demirciköy & " & " & 304 & " & 1 & - & 1 \\
\hline 319. Köşe Köy & » & " & 338 & " & 2 & - & 1 \\
\hline 320. Çorlu Koca & » & " & 351 & » & 1 & - & 1 \\
\hline 321. Kabakköy & " & " & 143 & " & 1 & - & - \\
\hline 322. Mitera Iskelesi & » & " & 130 & " & 1 & - & - \\
\hline
\end{tabular}


ETHNIC SURVIVAL, NATIONALISM AND FORCED MIGRATION

\begin{tabular}{|c|c|c|c|c|c|c|c|}
\hline$a^{\prime}$ & $\beta^{\prime}$ & $\gamma^{\prime}$ & $\delta^{\prime}$ & $\varepsilon^{\prime}$ & $\sigma \tau^{\prime}$ & $\zeta$ & $\eta^{\prime}$ \\
\hline 323. Musteci & Samsun & Canik & 148 & Turcophone & 1 & - & - \\
\hline 324. Alaçam & Alaçam & " & 1.516 & " & 2 & - & 1 \\
\hline 325. Kelik & Samsun & » & 137 & " & 1 & - & - \\
\hline 326. Antreoi & $"$ & $»$ & 223 & $»$ & 4 & - & 1 \\
\hline 327. Civli & » & » & 216 & " & 1 & - & 1 \\
\hline 328. Perkeli & " & » & 393 & " & 2 & - & 1 \\
\hline 329. Lara Hüseyin & " & " & 850 & " & 1 & - & 1 \\
\hline 330. Koz Köyü & " & » & 320 & » & 1 & - & 1 \\
\hline 331. Taş Çelik & " & » & 76 & " & - & - & - \\
\hline 332. Çelik & " & " & 254 & " & 1 & - & 1 \\
\hline 333. Cadırlık & * & » & 331 & " & 2 & - & 1 \\
\hline 334. Kazlı Viran & " & " & 446 & " & 3 & - & 1 \\
\hline 335. Meydanlık & " & $"$ & 193 & , & 1 & - & 1 \\
\hline 336. Ireklik & $»$ & " & 170 & $"$ & 1 & - & 1 \\
\hline TOTAL & & & 123.398 & & 462 & 5 & 310 \\
\hline
\end{tabular}


APPENDIX B

TABLE VII

GREEK SCHOOLS OF THE KRINI DIOCESE*

\begin{tabular}{|c|c|c|c|c|c|c|c|}
\hline & $a^{\prime}$ & $\beta^{\prime} \quad \gamma^{\prime}$ & $\delta^{\prime}$ & $\varepsilon^{\prime}$ & $\sigma \tau^{\prime}$ & $\zeta^{\prime}$ & $\eta^{\prime}$ \\
\hline 1. Krini (Çeşme) & Çeşme & 1 & 8 & 8 & 456 & 360 & $560 \mathrm{TL}$ \\
\hline 2. Alaçata & $"$ & 1 & 7 & 8 & 414 & 279 & $450 \mathrm{TL}$ \\
\hline 3. Kato Panagia & " & 1 & 3 & 4 & 253 & 206 & $240 \mathrm{TL}$ \\
\hline 4. Agia Paraskevi & " & 1 & 2 & 3 & 160 & 124 & $180 \mathrm{TL}$ \\
\hline 5. Ovacık & » & Mixed & 2 & 8 & 40 & 22 & $30 \mathrm{TL}$ \\
\hline 6. Reisdere & $"$ & 1 & 2 & 2 & 110 & 90 & $57 \mathrm{TL}$ \\
\hline 7. Kerme Yahısı & » & Mixed & 1 & 8 & 20 & 10 & $10 \mathrm{TL}$ \\
\hline 8. Aghrelia & $»$ & Mixed & 1 & 8 & 35 & 16 & $15 \mathrm{TL}$ \\
\hline 9. Pyrghi & $»$ & Mixed & 1 & 8 & 25 & 10 & $10 \mathrm{TL}$ \\
\hline 10. Erythrai & " & 1 & 2 & 1 & 86 & 75 & $75 \mathrm{TL}$ \\
\hline 11. Çı̈̆köy & $»$ & Mixed & 1 & 8 & 10 & 8 & $8 \mathrm{TL}$ \\
\hline 12. Ahirlı & Karaburun & 1 & 1 & 1 & 50 & 30 & $60 \mathrm{TL}$ \\
\hline 13. Sahibi & " & 1 & 1 & 1 & 40 & 60 & $70 \mathrm{TL}$ \\
\hline 14. Ambar-Seki & $"$ & Mixed & 1 & 8 & 10 & 5 & $8 \mathrm{TL}$ \\
\hline 15. Mikro Mourdouvani & " & 1 & 1 & 1 & 60 & 30 & $61 \mathrm{TL}$ \\
\hline 16. Tekkes & " & 1 & 1 & 1 & 50 & 40 & $50 \mathrm{TL}$ \\
\hline $\begin{array}{l}\text { 17. Mega Mourdouvani } \\
\text { (Inçepinar) }\end{array}$ & $n$ & 1 & 2 & 1 & 90 & 100 & $80 \mathrm{TL}$ \\
\hline 18. Monastırı & " & Mixed & 1 & 8 & 30 & 6 & 20TL \\
\hline 19. Tepepoz & " & Mixed & 1 & 8 & 50 & 25 & $20 \mathrm{TL}$ \\
\hline 20. Yeni Liman & " & Mixed & 1 & 8 & 50 & 25 & 20TL \\
\hline 21. Kaş-Seki & 》 & Mixed & 1 & 8 & 25 & 7 & $10 \mathrm{TL}$ \\
\hline 22. Şarbıncık & " & Mixed & 1 & 8 & 20 & 10 & $10 \mathrm{TL}$ \\
\hline 23. Sancak & ” & Mixed & 1 & 8 & 50 & 10 & $20 \mathrm{TL}$ \\
\hline 24. Boynak & $"$ & Mixed & 1 & 8 & 85 & 20 & $30 \mathrm{TL}$ \\
\hline 25. Salman & " & Mixed & 1 & 8 & 20 & 10 & $20 \mathrm{TL}$ \\
\hline 26. Eğri Liman & $»$ & Mixed & 1 & 8 & 10 & 5 & $10 \mathrm{TL}$ \\
\hline 27. Deniz Giren & " & Mixed & 1 & 8 & 17 & 19 & 26TL \\
\hline 28. Küçük Bahçe & " & Mixed & 1 & 8 & 15 & 15 & $8 \mathrm{TL}$ \\
\hline 29. Meli & » & Mixed & 2 & 8 & 130 & 80 & $80 \mathrm{TL}$ \\
\hline 30. Glezonisi & Vurla & Mixed & 1 & 8 & 85 & 25 & $35 \mathrm{TL}$ \\
\hline 31. Kioseni & $»$ & -- & - & - & - & - & \\
\hline 32. Agia Paraskevi & $»$ & Mixed & 1 & 8 & 15 & 10 & $10 \mathrm{TL}$ \\
\hline TOTAL & & $31 \quad 11$ & 53 & 31 & 2.511 & 1.732 & $2.283 \mathrm{TL}$ \\
\hline
\end{tabular}

* $a^{\prime}:$ Name of Kaza. $\beta^{\prime}$ : Number of boy's schools. $\gamma^{\prime}:$ Number of girls's schools. $\delta^{\prime}:$ Male teachers. $\varepsilon^{\prime}$ : Female teachers. $\sigma \tau^{\prime}$ : Number of boy students. $\zeta^{\prime}:$ Number of girl students. $\eta^{\prime}$ : School expenditure during academic year 1909-1910 in Turkish lira (TL). 